\title{
The Dutch in the Levant
}

\subsection{Straatvaart: Dutch Navigation into the Mediterranean}

During the last decades of the sixteenth century, ships originating from the Low Countries started to transport grain to Italian ports on a regular basis. This was the beginning of the so-called straatvaart, Dutch for 'navigation through the Strait [of Gibraltar]' (see figure 1). This involvement was part of a larger penetration of northern European commercial operations into the Mediterranean, often dubbed 'the northern invasion'.' Originally, Flemish merchants were behind many of these commercial voyages, but quickly, merchants from the Northern Netherlands equally became involved. This had to do with the migration of a substantial number of merchants from the Spanish Netherlands to cities in the north following the turmoil of the Eighty Years' War. The northern provinces had formally seceded from Spain in 1581 with the Act of Abjuration and proclaimed a Dutch Republic, the United Provinces, which quickly became an economic world power and experienced a 'golden age' during the seventeenth century. ${ }^{2}$

1 For the development of Dutch Mediterranean navigation, see Wilfrid Brulez, 'La navigation flamande vers la Méditerranée à la fin du XVIe siècle', Revue belge de philologie et d'histoire, 36:4 (1958): pp. 1210-1242; Maartje van Gelder, 'Supplying the Serenissima. The role of Flemish merchants in the Venetian grain trade during the first phase of the straatvaart', International journal of maritime history, 16:2 (2004): pp. 39-6o; Z.W. Sneller, 'Het begin van den NoordNederlandschen handel op het Middellandsche Zeegebied', Verslag Historisch Genootschap (1935): pp. 70-92; and J.H. Kernkamp, 'Het begin van den Noordnederlandsche scheepvaart op Italië', Tijdschrift voor geschiedenis, 49 (1934): pp. 70-93; see also Molly Greene, 'Beyond the northern invasion: The Mediterranean in the seventeenth century', Past \& present, 174:1 (2002): pp. 42-71.

2 This Dutch 'golden age' has been thoroughly studied. See, for instance, Maarten Prak, The Dutch Republic in the seventeenth century (Cambridge, 2005); Jonathan Israel, The Dutch Republic, its rise, greatness and fall (Oxford, 1995); John L. Price, Holland and the Dutch Republic in the seventeenth century: The politics of particularism (Oxford, 1994); Simon Schama, The embarrassment of riches: An interpretation of Dutch culture in the golden age (New York, 1987); and J.G. van Dillen, Van rijkdom en regenten. Handboek tot de economische en sociale geschiedenis van Nederland (The Hague, 1970). Today, the term 'golden age' has become controversial, and rightfully so, because this was a period with a heavy human toll caused by colonialism and the slave trade. 
The expansion of maritime trade and shipping to all corners of Europe, and across the Atlantic and Indian Oceans, played a central role in explaining Dutch economic advance during the seventeenth century. ${ }^{3}$ In the public eye, no enterprise exemplified that expansion more than the Dutch East India Company (VOC), but historians have also put a high emphasis on the role played by the 'mother trade', the commerce in grain with the Baltic region. ${ }^{4}$ Much of the imported grain was used in the United Provinces, where the older environment was not well suited for grain agriculture, but it was also reexported to Italian ports beginning in the 159 os. $^{5}$ Over time, Mediterranean navigation became more fully incorporated into the Dutch maritime enterprise as a whole and evolved into a structural branch of maritime commerce.

Dutch commercial activity at sea was expanding at a time of warfare and competition. In the Mediterranean, Dutch ships not only risked attacks from Spain or from corsairs operating out of the North African ports of Tunis, Algiers and Tripoli, but they also faced competition from French and English vessels. The young Dutch Republic quickly became aware of the need for legislation aimed at protecting its merchant marine. To that purpose, the convoys and licences (konvooien en licenten), a tax on foreign trade, was introduced by the States General in $1582 .{ }^{6}$ The tax was used to finance the navy, which was 'necessary to protect the merchant ships with convoys, fight the pirates and enforce the principle of free navigation at sea. ${ }^{7}$ Contrary to popular ideas that the decentralised Dutch navy did not work efficiently, Marjolein 't Hart has asserted that the navy was able to protect Dutch commercial interests at

3 Jonathan Israel, Dutch primacy in world trade, 1585-1740 (Oxford, 1989).

4 For the Baltic trade, see Milja van Tielhof, The 'mother of all trades.' The Baltic grain trade in Amsterdam from the late 16th to the early 19th century (Leiden and Boston, 2002). For the voc, see Femme Gaastra, The Dutch East India Company: Expansion and decline (Zutphen, 2003). Next to analysing the economic importance of the voc, as well as that of its Atlantic counterpart (the West India Company or WIC), recent scholarship has focussed more on the crucial issues of slavery and colonial oppression. See, for instance, Wim Klooster, The Dutch moment: War, trade, and settlement in the seventeenth-century Atlantic world (Ithaca, NY, 2016); and, for the Atlantic context, Karwan Fatah-Black and Matthias van Rossum, 'Beyond profitability: The Dutch transatlantic slave trade and its economic impact', Slavery \& abolition, 36:1 (2015): pp. 63-83; and, for the Asian context, Markus P.M. Vink, 'Freedom and slavery: The Dutch Republic, the VOC world, and the debate over the "world's oldest trade"', South African historical journal, 59:1 (2007): pp. 19-46.

5 Brulez, 'La navigation flamande'; and van Gelder, 'Supplying the Serenissima'.

6 These were taxes on imported and exported goods, installed by the States General but collected by the five Admiralties (Amsterdam, Rotterdam, West Frisia, Zeeland and Frisia) of the navy, each in their own jurisdiction. See Israel, Dutch primacy, p. 28 o.

7 De Vries and van der Woude, Nederland, p. 127. 
sea: 'the five Boards [of Admiralty] were nominally under the authority of the States-General but they all evolved into rather independent institutions, with strong links to local mercantile elites. The Amsterdam Admiralty soon became the most prominent. Its customs officers gathered most revenues, which were obviously connected to the size and wealth of its district and reflected the trading strength of Amsterdam.8 It was quickly understood that naval protection should be complemented with a number of additional regulations for merchant marine vessels. In 1596, the States of Holland issued an ordinance that introduced standards for the armament of vessels undertaking commercial voyages through the Sound, the maritime strait between Denmark and Sweden. ${ }^{9}$ Seven years later, the States General issued the first of a series of laws dealing with 'the armament and manning of the ships, merchant vessels as well as the fisheries, sailing from the United Provinces to the sea.. ${ }^{10}$ The ordinance also included the establishment of a convoy system. Merchant marine ships were obliged to sail as a convoy under the protection of navy ships. Additional clauses stipulated that merchant marine ships needed to carry a minimum armament and crew, depending on a ship's freight capacities. ${ }^{11}$ A ship able to carry between 190 and 200 last, for instance, was obliged to sail with at least twenty-two men, three

Marjolein 't Hart, The Dutch wars of independence: Warfare and commerce in the Netherlands, 1570-1680 (London and New York, 2014), p. 127. Chapter six of this work deals with the early development of the Dutch navy and its role in protecting commercial interests (pp. 126-147). National Archives The Hague (hereafter NA), 3.01.04.01 (Archief van de Staten van Holland en West-Friesland, 1572-1795), $\mathrm{N}^{\circ}{ }_{1357} \mathrm{OO}$ ('Ordonnantie van de Admiraal- Generaal en de Staten van Holland ter beveiliging van de handelsscheepvaart op het Oosten en de Sont', 1596).

10 Nederlandtsche placcaet-boeck: Waerinne alle voornaemste placcaten, ordonnantien, accorden, ende andere acten ende munimenten, uyt-ghegeven by de EE. hoog-mogende heeren Staten Generael der Vereenigde Nederlantsche provintien; Sedert dat Philippus II. koninck van Spagnien eerst verclaert is, vervallen te wesen vande hoogh-overigheyt deser landen, in't jaer 1581, tot op den teghenwoordighen jaere 1644 (Amsterdam, 1644), 1: pp. 29230o, 'Placcaet ende ordonnantie, op de wapeninghe ende manninge van de schepen, soo ter koopvaerdye als visscherye uyt de Vereenighde Nederlanden over zee varende, midtsgaders op de ordre van de Admiraelschappen ende 't beleydt van dien, met het gene daer aen dependeert', o9/o4/1603. This regulation was reissued on several occasions (23/02/ 1607, 22/o7/1625, 16/o1/1627, 17/03/1627, 20/10/1628, 19/03/1629, 24/12/1630 and 11/03/1632), with some slight modifications from time to time.

11 See, for instance, Nederlandtsche placcaet-boeck, 1: pp. 426-429, 'Ordre, by de hooghmogende heeren Staten Generael der Vereenighde Nederlanden, gemaeckt op het bevaren van de Middellantschse Zee, ende het zout-halen in West-Indien', 27/10/1621. The Dutch convoy system was even popular among non-Dutch skippers. See, for instance, NA, $\mathrm{N}^{\circ}$ 1.01.02, 'Archief van de Staten-Generaal, (1431) 1576-1796' (hereafter NASG), $\mathrm{N}^{\circ}{ }_{12561.151 .4}$ ('Stukken betreffende het verlenen van convooi aan Hamburgse schepen varende op de Middellandse Zee, 1664'), which contains material concerning the assistance given by Dutch warships to merchantmen sailing to the Mediterranean under the 
boys and sixteen cannons, as well as muskets and pikes. ${ }^{12}$ The commercial routes that were mentioned included Norway and the Baltic, France, the East and West Indies, Guinea and the Mediterranean. ${ }^{13}$

Initially, vessels sailing through the Strait of Gibraltar were exempt from the convoy system. Dutch Mediterranean navigation was still in its infancy and relatively small in comparison to the fleet of herring fishermen or the merchantmen sailing to Scandinavia and the Baltic. The Twelve Years' Truce (16o91621) between Spain and the United Provinces proved to be very beneficial for the development of Dutch navigation in the Mediterranean. The truce led to the lifting of Spanish embargoes against the Dutch, who managed to acquire an important piece of the carrying trade between Spain and Italy. Dutch vessels shipped wool and salt to Genoa, Livorno and Venice and became the most important carriers of salt from Valencia to Italy, and of grain from Sicily and Puglia to eastern Spain. ${ }^{14}$ Amsterdam was becoming a staple market for Asian pepper and spices, and Dutch skippers increasingly exported these commodities to places such as Genoa, Livorno and ports in the Levant, successfully competing with English, Venetian and Genoese merchants and ship owners. ${ }^{15}$

Hamburg flag; see also Arie Bijl, De Nederlandse convooidienst. De maritieme bescherming van koopvaardij en zeevisserij tegen piraten en oorlogsgevaar in het verleden (The Hague, 1951).

12 One last was about 2,ooo kilos. On the average volume of Mediterranean shipping, see Tijl Vanneste, 'Sailing through the straits: Seamen's professional trajectories from a segmented labour market in Holland into a fragmented Mediterranean', in Labour, law, and empire: Comparative perspectives on seafarers, c. 1500-1800, eds. Maria Fusaro, Bernard Allaire, Richard Blakemore, and Tijl Vanneste (Basingstoke, 2015), pp. 123-140.

13 Nederlandtsche placcaet-boeck, 1: pp. 292-300, 'Placcaet ende ordonnantie', o9/04/16o3.

14 Israel, Dutch primacy, p. 97.

15 Ibid. Part of that success stemmed from lower Dutch freight charges. The war with Spain influenced the growth rate of Dutch commercial expansion, but historians do not fully agree on a timeline. Jonathan Israel provided an alternative narrative about Dutch economic growth during the war with Spain that was contended by Dutch historians such as Jan Luiten van Zanden and Leo Noordegraaf. Israel asserted that, contrary to common opinion, the period between 1621 and 1647 was a low point, partly owing to the end of the truce between the Republic and Spain, while the phase that followed, between 1647 and 1672 , was the zenith of economic prosperity. Israel, Dutch primacy. For the criticisms, see Jan Luiten van Zanden, 'Een fraaie synthese op een wankele basis', BMGN - Low Countries historical review, 106:3 (1991): pp. 451-457; and Leo Noordegraaf, 'Vooruit en achteruit in de handelsgeschiedenis van de Republiek', BMGN - Low Countries historical review, 106:3 (1991): pp. 458-468. For Israel's reply, see Jonathan Israel, "The "new history" versus "traditional history" in interpreting Dutch world trade primacy', $B M G N$ - Low Countries historical review, 106:3 (1991): pp. 469-479. For a debate on the different phases of Dutch Mediterranean navigation during the early modern period, see Jonathan Israel, 'The phases of the Dutch straatvaart (1590-1713): A chapter in the economic history of the 
Throughout the seventeenth century, Dutch ships also managed to obtain a higher share in intra-Mediterranean trade. Technological innovation, such as the fluyt ship, allowed the Dutch to ship at a lower cost than many of their competitors, and they increasingly acted as transport carriers for commercial journeys between Mediterranean cities, at the expense of Genoese, Greek and Venetian vessels. ${ }^{16}$ These growing private successes in such an international and competitive region were recognised by the States General, which now granted their full support. Immediately after the resumption of hostilities with Spain in 1621, a new set of directives was issued that specifically aimed at regulating Dutch commercial navigation in the Mediterranean. Danger not only came from Spain but also from the North African corsairs, who wanted 'to rob the same good inhabitants [trading through the Strait of Gibraltar to the lands adjacent to the Mediterranean Sea in the Levant and the archipelago] of all commerce and traffic at sea, and to kill them, take their goods and make them bleed. ${ }^{17}$ The States General published a regulation instructing all ships leaving the United Provinces to register their cargos. Skippers who intended not to sail through the strait had to issue an explicit declaration confirming their destination. ${ }^{18}$ Ships who did intend to sail into the Mediterranean were now also subject to the convoy system. The Boards of Admiralty were ordered to supply six well-armed warships, each at least 200 lasts in size, to assist straitbound convoys composed of thirty to forty merchant vessels. Specific assembly points were stipulated, and skippers had to swear an oath with which they promised to fight the enemy when the convoy commanders asked them to do so. ${ }^{19}$ From this moment onwards, private maritime enterprise through the

Mediterranean', Tijdschrift voor geschiedenis (1986): pp. 1-3o. An analysis of Israel's division, in which his reliance on political events is questioned, is provided by P.C. van Royen, 'The first phase of Dutch straatvaart (1591-1605): Fact and fiction', International journal of maritime history, 2 (199o): pp. 69-102.

16 Marie-Christine Engels, Merchants, interlopers, seamen and corsairs. The 'Flemish' community in Livorno and Genoa (1615-1635) (Hilversum, 1997), pp. 118-119; and Jessica V. Roitman, The same but different? Inter-cultural trade and the Sephardim, 1595-1640 (Leiden and Boston, 2011), p. 187. For the link between transport costs and intra-Mediterranean coastal trade, see de Vries and van der Woude, Nederland, pp. 447.

17 Nederlandtsche placcaet-boeck, 1: pp. 424-426, 'Placcaet, inhoudende verbodt dat niemandt varen en magh door de Strate van Gibraltar ofte near de zout-vaert, anders als in Admiraelschap, ende met convoy: Uytgegeven by de hoogh-mogende heeren Staten Generael der Vereenighde Nederlanden', 27/10/1621, on p. 425, '[...] omme deselve goede inghesetenen van alle commercien ende trafficque ter zee te berooven, ende deselve om lijf, goedt, ende bloedt te brenghen [...]'.

18 Ibid.

19 Evidence for the constant negotiating process between cities with regard to their national responsibilities, as well as Amsterdam's dominant role, can be found in the stipulation 
Strait of Gibraltar was regulated by the States General. Dutch navigation into the Mediterranean became a matter of 'national interest', although the cities continued to play their role. ${ }^{20}$

\subsection{The Directorate of Levant Trade and European Competition}

The successes of the Dutch straatvaart led to expansion into the eastern Mediterranean, and Dutch vessels started to arrive with more regularity in ports in the Levant. Institutionally, this commercial expansion had two important consequences. First, the Dutch presence in the eastern Mediterranean warranted the establishment of diplomatic ties with the Ottoman Empire. An additional need for such ties was the growing presence of Dutch seamen amongst the Christian captives of corsairs from the North African city states, which formally fell under Ottoman control. Discussing terms of liberation for Christian captives was an essential part of the missions given to early Dutch envoys to Morocco and the Ottoman Empire. A second was the negotiation of military assistance in the fight against a common enemy - Spain..$^{21}$ In earlier years, attempts had been made to form an anti-Spanish alliance between the Ottoman Empire, the United Provinces and Morocco. ${ }^{22}$ A Dutch envoy,

that the Admiralties of Westfrisia (Enkhuizen, Medemblik and Hoorn), Rotterdam and Zeeland each had to contribute one ship, while Amsterdam had to provide three. Nederlandtsche placcaet-boeck, 1: 426-429, 'Ordre, by de hoogh-mogende heeren Staten Generael', 27/10/1621. The text of the oath can be found on pp. 430-431.

20 The legislation concerned with maritime protection mentioned in the previous footnotes persistently labelled fraud in the payment of taxes that covered maritime protection and infractions against armament and crew size regulations as harmful to the 'national good'.

21 De Groot, The Ottoman Empire, pp. 55-58.

22 There was Dutch agent in Morocco, Pieter Coy, between 1605 and 1609 (in 1625 he was sent to Algiers). Coy had to promote Dutch trade and shipping as well as negotiate for the liberation of Dutch Christian captives. Otto Schutte, Repertorium der Nederlandse vertegenwoordigers residerende in het buitenland 1584-1810 (The Hague, 1976), p. 381. This work provides a complete overview of Dutch diplomatic representation abroad until the first decade of the nineteenth century. Negotiations between Morocco and the Dutch took place through the involvement of Samuel Pallache, Morocco's Jewish agent residing in The Hague. See Otto Schutte, Repertorium der buitenlandse vertegenwoordigers, residerende in Nederland ${ }^{584-1810}$ (The Hague, 1983), pp. 579-580. This work contains biographical information on diplomatic representatives of foreign rulers until the first decade of the nineteenth century and is the complement to Schutte's earlier publication on Dutch representatives abroad that was previously mentioned. For an analysis of the attempted military alliance, see Klaas Heeringa, 'Een bondgenootschap tussen Nederland en Marokko', Onze eeuw, 7:3 (1907): pp. 81-119. A recent biography of Pallache by Mercedes García-Arenal and Gerard Wiegers, Samuel Pallache. Koopman, kaper en diplomaat tussen Marrakesh en Amsterdam (Amsterdam, 2014) discusses the military alliance talks as 
Cornelis Haga, was sent to Istanbul; he arrived in 1612 to negotiate a peace treaty with the sultan. ${ }^{23}$

Plans for a concrete alliance never resulted in a military partnership, but Haga quickly manage to befriend Grand Admiral Halil Pasha, which contributed to the rapid conclusion of an Ottoman-Dutch treaty only four months after Haga's arrival in the Ottoman capital. The treaty resulted in the establishment of the first Dutch capitulations, which arranged Dutch presence in the Ottoman Empire, following existing capitulations given to the French, English and Venetians. ${ }^{24}$

By the time of Haga's mission, the Dutch had already established a consular outpost in Syria, in Aleppo, to protect the interests of traders there, but Dutch Levant merchants made the need for the further institutionalisation of their commercial activities clear in advice to the States General and the provincial States, leading to further institutional innovation. In 1625, Amsterdam merchants successfully petitioned their burgomasters to install a Directorate of Levant Trade. ${ }^{25}$ The directorate was not a company but a supervisory board of merchants, called into existence with the support of the Dutch ambassador in Istanbul, Cornelis Haga. Its main functions were to supervise ships' compliance with all existing legislation that regulated Mediterranean navigation, to control collection of maritime taxes, to verify ships' papers and to maintain correspondence with the Dutch ambassador in Istanbul and the consuls in the Levant and North Africa. ${ }^{26}$ The Directorate of Levant Trade also played an

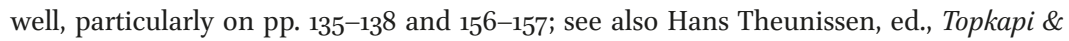
turkomanie. Turks-Nederlandse ontmoetingen sinds 1600 (Amsterdam, 1989).

23 For a detailed description of the choice of Cornelis Haga, a diplomat with a law degree from Leiden University and son of rich parents originating from Schiedam, see de Groot, The Ottoman Empire, pp. 57-113. After his mission as envoy ended, Haga became the first Dutch ambassador in Istanbul, a function he occupied until 1639, when he returned to the United Provinces. For an overview of his tenure, see ibid., pp. 114-127. A recommendable recent biography of Cornelis Haga is Ingrid van der Vlis and Hans van der Sloot, Cornelis Haga 1578-1654. Pionier en diplomaat in Constantinopel (Amsterdam, 2012).

24 The capitulations are discussed in detail on pp. 28-39.

25 The burgomasters (burgemeesters) were the most influential magistrates in Amsterdam's governing body, the vroedschap, the thirty-six members of which came from the city's ruling elite, the so-called regent families. See Julia Lindemann, "Dirty politics or "harmonie"? Defining corruption in early modern Amsterdam and Hamburg', Journal of social history, 45:3 (2012): pp. 586-588.

26 A copy of the original act establishing the Directorate of Levant Trade on 25 June 1625 can be found in the archives of the Directorate; NA, 1.03.o1, 'Archief van de Directie van de Levantse Handel en de Navigatie in de Middellandse Zee, (1614) 1625-1826 (1828)' (hereafter NALH), 'Directie Amsterdam', Nº86 ('Nominatieboek', 1625-180o), on the first six folios. On the history and functioning of the directorate, see also Heeringa and Nanninga, Bronnen tot de geschiedenis, 2: pp. 1-107. 
important role in setting up the playing field for Dutch consuls; it 'drew up lists of nominees for consular appointments, set the consuls' salaries and drafted their instructions', while the final political responsibility for the consulates remained with the States General. ${ }^{27}$

Initially, there was only a directorate in Amsterdam, consisting of seven directors, all important Levant traders chosen by the burgomasters. Some of them were replaced on a yearly basis, but others stayed on for several years. ${ }^{28}$ In 1644, a separate directorate was established in Hoorn, followed by new directorates in Rotterdam (1674) and Middelburg (1696). In 1668, the Amsterdam directorate had accepted the inclusion of one merchant from Leiden, as that city maintained an important cloth trade with Izmir. ${ }^{29}$ The directors of each directorate met once a week, and once a year they all met in a general meeting. Besides their administrative and fiscal functions, the Directorate of Levant Trade also petitioned Dutch governmental bodies about the development of Levant trade. The States General often required their assistance and advice on all matters pertaining to navigational, commercial and political matters in the eastern Mediterranean, and the directorates also cooperated with the Admiralty Boards in matters of naval protection. In addition to the directors, the Directorate of Levant Trade engaged a number of civil servants. In 1749, for instance, documentation shows that the Amsterdam Directorate of Levant Trade employed a secretary, a tax collector, an appraiser and a clerk. ${ }^{30}$

The expenses of the Directorate of Levant Trade were funded by several taxes levied directly on shipping. The first was the lastgeld, a weight-based tax paid by each Dutch ship setting out to sail through the Strait of Gibraltar. It was set at sixteen pennies per last of cargo space, with two-thirds of the amount provided by the cargo owners and one-third by the ship's owners. Later, foreign vessels leaving Dutch ports were also subject to the tax, which was raised to twenty pennies. ${ }^{31}$ A second tax, the vrachtgeld, was established in 1671. It was

27 Albert E. Kersten and Bert van der Zwan, 'The Dutch consular service: In the interests of a colonial and commercialised nation', in Consular affairs and diplomacy, eds. Jan Melissen and Ana Mar Fernández (Leiden, 2011), p. 277.

28 NALH, 'Directie Amsterdam', $\mathrm{N}^{\circ} 1$ ('Resolutieboek', o4/10/1627-21/12/1663).

29 A.H.H. van der Burgh, Inventaris van het archief van de Directie van de Levantse Handel en de Navigatie in de Middellandse Zee, (1614) 1625-1826 (1828) (The Hague, 1882), pp. 18-20.

$30 \quad$ Hakkı Kadı, Ottoman and Dutch merchants, p. 155.

31 These taxes, based on the size of ships, were called 'lastgelden'. Nederlandtsche placcaetboeck, 2: pp. 13-17, 'Placcaet, ende ordonnantie vande hooge ende moghende heeren Staten Generael der Vereenighde Nederlanden, waer near de inghesetenen vande selve landen, varende near westen, door de Strate, ofte Engte van Gibeltar, om te negotieren op Levante, ende op de rijcken vanden grooten heere tot Constantinopolen, ofte mede binnen de voorsz. Strate, op Vranckrijck, ende Italien, hen sullen hebben te reguleren, ten 
a levy of $5 \%$ on the value of all goods that arrived in Dutch ports from Izmir, and later also from other places in the Levant. Originally it only applied to Dutch ships, but in 1770 , it was extended to include foreign vessels. ${ }^{32}$ During the eighteenth century, a third tax existed, the tanza, or levantrecht. A decree by the States General issued in 1749 fixed this tax at $1.5 \%$ on Levantine goods arriving in all ports of the United Provinces under any flag. ${ }^{33}$ These taxes were used as means of pressure in political conflict between cities. In 1630 and 1631, for instance, the city of Hoorn refused to pay the lastgelden unless their merchants would also receive a seat in the Directorate of Levant Trade, a demand that was met by the States General in $1633 .{ }^{34}$

regarde van hare zee-brieven, betalinghe van last-gelden, ende andersints', 24/06/1625. The tax receivers of the Admiralty colleges already collected the convoys and licenses tax (see p. 18); see also W.F.H. Oldewelt, De oudste lastgeldrekening van Directeuren van de Levantse handel (1625-1631) (Amsterdam, 1958).

32 Van der Burgh, Inventaris, pp. 21-23.

33 Hakkı Kadı, Ottoman and Dutch merchants, p. 156. Originally, the tanza had been raised on goods arriving in Dutch ports from Syrian Aleppo and Cyprus to cover the expenses of the consulates there. See Engels, Merchants, interlopers, p. 7o. During the seventeenth century, it was used as a temporary tax on goods to cover a number of extraordinary expenses, such as the compensation demanded by the sultan after the Dutch vessel Keizer Octavianus had been taken by Christian corsairs in 1662, which caused a loss of cargo belonging to Ottoman traders. The demanded amount of 78,445 lion dollars was financed by a tanza of $1 \%$ on all goods shipped on Dutch vessels sailing from and to the Levant. NALH, 'Directie Amsterdam', $\mathrm{N}^{\circ} 238$ ('Diverse stukken'), 'Extract resolutieboek vroedschap', fo 45, 16/10/1663; see also the set of documents in NALH, 'Directie Amsterdam', $\mathrm{N}^{\circ} 238$ ('Diverse stukken'), 'Stukken betreffende het geschil tussen de Admiraliteit te Amsterdam en de Directie over een schuld van ruim 37.0oo gulden in het jaar 1633 door de ontvanger Hoefijser aangegaan', 1668-1669. The tax was levied for several years and caused friction between several directorates and admiralties. It even led to a discussion on urban competition and the difference between commercial navigation and commerce in the work of one of Holland's foremost early modern thinkers, Pieter de la Court, Aanwysing der heilsame politike gronden en maximen van de Republike van Holland en West-Vriesland (Leiden and Rotterdam, 1669), pp. 122-126. The leeuwendaalder (in English 'lion dollar') was a silver currency that was very popular in the Levant and often used by Dutch merchants to settle the balance of trade. See Ton Kappelhof, Dukaten, daalders en duiten -Een geschiedenis van het geld (Zwolle, 2006), pp. 34-35. New coins were no longer issued after 1712, and it was worth forty-two pennies of the Holland guilder. Willlem Sewel and Egbert Buys, Volkomen woordenboek der Nederduitsche en Engelse talen; Névens eene spraak-konst van dezelven/A compleat dictionary Dutch and English to which is added a grammar, for both languages, 4th ed. (Amsterdam, 1766 [1691]), 2: p. 443.

34 NALH, 'Directie Amsterdam', N ${ }^{\circ}$, pp. 52-53, 68; and $\mathrm{N}^{\circ} 73$ ('Remonstrantieboek', 16271649), pp. 94, 102-103, and 125. Hoorn, in West Frisia, was an important city in the straatvaart. See Hermann Wätjen, Die Niederländer in Mittelmeergebiet zur Zeit ihren hochsten Machtstellung (Berlin, 1909), p. 114. 
It seems that the decentralised nature of the Dutch state helped Dutch commercial expansion in the Levant: 'the normal business environment in the Levant was not one where uniform policies [...] closely coordinated and controlled from central command in northern Europe, could hold sway $[\ldots]^{35}$ That did not mean, however, that all the other European states with whom the Dutch competed adopted similar policies. ${ }^{36}$ In 1569 , the French had become the first western European power to obtain capitulations from the Ottoman sultan. ${ }^{37}$ Merchants operating out of Marseille had obtained a quasi-monopolistic position in French Levant trade through the Chamber of Commerce, and after 166o, Louis XIV established firm control of the French Mediterranean port. The Marseille traders sent their representatives to important Levantine scales where they were supported by the French diplomatic network. ${ }^{38}$ In this way they managed to expand their activities at the expense of other European nations, and by the 175os, Marseille traders controlled over $60 \%$ of the volume of European Levant trade..$^{39}$

The other important western European state to compete with the Dutch in the Levant was England. ${ }^{40}$ The Levant Company was established in London in 1592 as the fusion of two older companies trading with the Mediterranean, the Venetian Company and the Turkey Company. Merchants who purchased membership to the company were allowed to act as independent traders, but nobody outside the company was allowed to trade directly with the Levant,

35 Rhoads Murphey, 'Merchants, nations, and free-agency: An attempt at a qualitative characterization of trade in the eastern Mediterranean, 1620-1640', in Friends and rivals in the east. Studies in Anglo-Dutch relations in the Levant from the seventeenth to the early nineteenth century, eds. A. Hamilton, A.H. de Groot, and M.H. van den Boogert (Leiden and Boston, 200o), p. 53 .

36 For a general overview of the different efforts made by various European states in the Levant, see Alexander H. de Groot, "The organization of western European trade in the Levant, 1500-1800', in Companies and trade. Essays on overseas trading companies during the Ancien Régime, eds. L. Blussé and F. Gaastra (Leiden, 1981), pp. 231-241.

37 These will be discussed in more detail on pp. 32-34.

38 For the establishment of Marseille as the centre of French trading activities with the eastern Mediterranean, see Juno T. Takeda, Between crown \& commerce: Marseille and the early modern Mediterranean (Baltimore, 2011).

39 Edhem Eldem, 'French trade and commercial policy in the Levant in the eighteenth century', Oriente moderno, nuova serie, 18:1 (1999): pp. 27-47; see also Joseph Billioud and Raymond Collier, Histoire du commerce de Marseille: de 148o à 1599, vol. 3 of Histoire du commerce de Marseille, ed. Gaston Rambert (Paris, 1951).

40 Already fierce enemies at sea for regular intervals during the three Anglo-Dutch wars of the seventeenth century, the English and the Dutch battled for Levantine primacy as well. See Jonathan Israel, 'Trade, politics and strategy: The Anglo-Dutch wars in the Levant (1647-1675)', in Friends and rivals, eds. Hamilton et al., pp. 11-23. 
creating a monopoly for the group of mainly London-based traders who were its members. ${ }^{41}$ Perhaps the main victim of the western European institutionalisation of their commercial operations in the Levant was Venice, which had long been a dominant factor in the eastern Mediterranean. ${ }^{42}$

The French and English Levant trades relied on centralisation and the establishment of monopolies, particularly successful in the French case, but the Dutch 'were the only nation among the major western European trade partners of the Ottoman Empire who pursued free trade policies in the Levant.'43 This is a very important consideration, as it was the main cause behind the high participation of non-Muslim Ottoman traders in commerce between the United Provinces and the Levant. It also meant that, initially, trading communities of Dutch merchants were able to develop independently, without much interference from political institutions at home. Dutch communities had been established across the Mediterranean in Venice, Livorno, Genoa, Izmir and Syrian Aleppo. They all had developed with a certain degree of autonomy before requesting the States General for a formal diplomatic presence to better regulate Dutch trade. ${ }^{44}$ Autonomy always remained an important feature of Dutch commercial communities abroad, in parallel to the political

41 See Fusaro, Political economies, particularly pp. 48-51 for the Venice and Turkey Companies, as well as pp. 64-88 for the Ottoman Levant; see also Despina Vlami, Trading with the Ottomans. The Levant Company in the Middle East (London and New York, 2014); Alfred C. Wood, A history of the Levant Company (Oxford, 1935); and Mortimer Epstein, The early history of the Levant Company (London, 1908). For a more general discussion of England's trading operations at the time, see Robert Brenner, Merchants and revolution. Commercial change, political conflict, and London's overseas traders, 1550-1653 (Princeton, 1993); and David Ormrod, The rise of commercial empires: England and the Netherlands in the age of mercantilism, $1650-1770$ (Cambridge, 2008).

42 For an excellent analysis of this evolution, see Fusaro, Political economies; see also Suraiya Faroqhi, 'The Venetian presence in the Ottoman Empire (1600-1630)',Journal of European economic history, 15 (1986): pp. 345-384. For the competition between the English and the Dutch in eighteenth-century Izmir, see Elena Frangakis-Syrett, 'Commercial practices and competition in the Levant. The British and the Dutch in eighteenth-century Izmir', in Friends and rivals, eds. Hamilton et al., pp. $135^{-158}$.

43 Hakkı Kadı, Ottoman and Dutch merchants, p. 154.

44 For Venice, see van Gelder, Trading places; and Daniel Koster, The conquering Dutch merchants and shipowners (Venice, 2006). For Livorno and Genoa, see Engels, Merchants, interlopers; and 'Dutch traders in Livorno at the beginning of the seventeenth century. The company of Joris Jansen and Bernard van den Broecke', in Entrepreneurs and entrepreneurship in early modern times. Merchants and industrialists within the orbit of the Dutch staple market, eds. C. Lesger and L. Noordegraaf (The Hague, 1995), pp. 63-76. Not much scholarship exists for Izmir, the exception is Jan Willem Samberg, De Hollandsche gereformeerde gemeente (Leiden, 1928). 
autonomy that existed in the United Provinces as well. Policies in the Levant were often discussed with the Directorate of Levant Trade, which meant that the functioning of Levant trade continued to receive strong impulses from the cities - Amsterdam first of all - even when Dutch commercial enterprise in the Levant, the Mediterranean and the Ottoman Empire became a matter of 'national interest'. The inheritance of local autonomy at times clashed with the efforts of Dutch institutional control, which was in any case divided by the urban institutions of the Directorate of Levant Trade and the national institution of the States General.

The Dutch Levantine Institutional Context

2.1

A Short History of the European Capitulations

With the establishment of the Directorate of Levant Trade, Levant trade was as regulated as it would ever be in the United Provinces. The establishment of a second institutional framework in the Levant was more important, but also more complicated. Throughout the early modern period, the legal, political and administrative context in which the Dutch and other European trading communities operated was created and controlled by the Ottoman Empire.45 All European trading communities that wished to settle in an Ottoman city needed to obtain permission from the sultan. The continuous physical presence of Dutch traders on Ottoman soil was a privilege allowed by the Porte, and it was regulated on the basis of periodically renewed treaties that were called 'capitulations', or ahdnames. They provided a crucial part of the legal context within which these communities were permitted to operate and allowed for Dutch diplomatic representation to be established in the places where Dutch traders were active.

The capitulations applied to all members of the trading nation to whom they had been granted and were supplemented by additional legislation issued through fermans, the sultanic decrees. These two, together with a third type of legal document called the berat, formed the written corpus that institutionalised the European presence in the Ottoman territories. Different from the capitulations, which were collective, and the fermans, which addressed particular issues, berats were individual deeds of appointment to a position and were necessary for everyone who wanted to hold a bureaucratic position, Ottomans as well as Europeans. They described the authority and responsibility that

Van den Boogert, The capitulations, pp. 26-29. 
came with the function and formed an official authorisation from the sultan for that person to take up the position for which the berat had been drafted. ${ }^{46}$ Without these berats, European diplomats could not function in the Ottoman Empire, as their domestic appointments alone, in the Dutch case by the States General, were not considered sufficient by the Porte. Ottomans working for Europeans, such as interpreters, who were called 'dragomans', also needed a berat. ${ }^{47}$

But European employment was not the only reason an Ottoman subject might need a berat. The document also needed to be drafted for non-Muslim Ottomans who had purchased European legal protection. ${ }^{48}$ These men were sometimes referred to as beratlıs (holders of a berat) but were also called protégés or 'honorary dragomans'. Only non-Muslim Ottoman subjects, particularly Jews, Greeks and Armenians qualified for protection status, and the title of honorary dragoman referred to the origins of the practice, which had grown out of the possibility of European diplomats hiring non-Muslim Ottomans as interpreters, or dragomans, who became then attached to European embassies and consulates in the Ottoman Empire. Dragomans enjoyed a number of privileges, which were described in the capitulations, such as tax exemption. Over

46 Bülent Arı, 'Early Ottoman diplomacy: Ad hoc period', in Ottoman diplomacy: Conventional or unconventional?, ed. A. Yuri Nurdusev (Basingstoke and New York, 2004), p. 41.

47 Dragomans were mediators, and as official interpreters, all European embassies and consulates had a number of them in their employment. See E. Nathalie Rothman, The dragoman renaissance. Diplomatic interpreters and the routes of Orientalism (Ithaca, NY, 2021); Éva Á. Csató, Bernt Brendemoen, Lars Johanson, Claudia Römer, and Heidi Stein, 'The linguistic landscape of Istanbul in the seventeenth century', in The urban mind. Cultural and environmental dynamics, eds. Paul J.J. Sinclair, Gullög Nordquist, Frands Herschend, and Christian Isendahl (Uppsala, 2010), pp. 415-439; E. Nathalie Rothman, 'Interpreting dragomans: Boundaries and crossings in the early modern Mediterranean', Comparative studies in society and history, 51:4 (2009): pp. 771-80o; Alexander H. de Groot, 'Die levantischen Dragomanen. Einheimische und Fremde im eigenen Land. Kultur- und Sprachgrenzen zwischen Ost und West (1453-1914)', in Verstehen und Verständigung:Ethnologie, Xenologie, Interkulturelle Philosophie, ed. Wolfdietrich Schmied-Kowarzik (Würzburg, 2001), pp. 110127; Frédéric Hitzel, ed., Enfants de langue et drogmans (Istanbul, 1995); and Alexander H. de Groot, 'Dragomans' careers: Change of status in some families connected with the British and Dutch embassies in Istanbul (1785-1829)', in Friends and rivals, eds. Hamilton et al., pp. 223-246. The position of dragoman came with certain privileges, and several families managed to make the position hereditary, creating dragoman dynasties.

48 Van den Boogert, The capitulations, pp. 25-26. For a French translation of such a berat given to Consul Haanwinkel in Aleppo in 1753, see Heeringa and Nanninga, Bronnen tot de geschiedenis, 3: pp. 249-251, 'Traduction du barat ou brevet imperial, que la Sublime Porte a accordé en faveur de mr le consul d'Alep Hannewinkel vers le 11 janv. 1753'. In the text, several of the capitulatory articles, which dealt with the consul's specific privileges, as well as his responsibilities, were repeated. 
time, what had begun as employment developed into a status as protégé of a particular European state, bought by those interested in using the privileges attached to it. ${ }^{49}$

Initially, the capitulations had come into being for the benefit of southern European traders, who had become increasingly involved in Europe's trade with the Levant, even before the Ottoman conquest of Constantinople. ${ }^{50}$ As early as 1082, the Byzantine emperor Alexius I Comenus had given the Venetians certain privileges, which included tax exemptions, right of Latin worship and Venetian jurisdiction over a Venetian quarter, including the establishment of judges who adjudicated in cases where Venetians were defendants. ${ }^{51}$ Commercial relationships, and the diplomatic connections enabling these relationships, had been expanding since the Middle Ages, with a growing number of transactions taking place with merchants in Muslim territories. Both the import of European cloths and linen into the Muslim Levant and the export of Oriental textiles to Europe continued throughout the fourteenth century, with the heavy involvement of Catalan, Venetian and Genoese traders. ${ }^{52}$ These three trading nations competed with one another, and Venice came out as the dominant European commercial actor in the eastern Mediterranean, including the Levant, during the first decades of the fifteenth century. ${ }^{53}$ The expansion of the Ottoman Empire and the conquest of Constantinople in 1453 fundamentally altered Levant trade, leading European traders to forge stronger commercial ties with the Mamluk sultanate in present-day Egypt. At the same time, European diplomatic missions to the Porte attempted to obtain guarantees allowing European trading communities to continue their activities as before. Supplementing their treaties with Byzantium, Venice concluded a number of important peace treaties with the Ottomans in 1446, 1451 and 1454, all dealing with matters of territorial claims between the two and

49 For the beratlıs, see pp. 61-64. Litigation involving them will be discussed in chapter five.

50 For the long relationship between Venice and Byzantium, see S. Borsari, Venezia e Bisanzio nel XII secolo: I rapporti economici (Venice, 1988); and Donald M. Nicol, Byzantium and Venice: A study in diplomatic and cultural relations (Cambridge, 1988).

51 Marco Pozza and Giorgio Ravegnani, I trattati con Bisanzio, 992-1198 (Venice, 1993), pp. $35-45$.

52 Eliyahu Ashtor, Levant trade in the Middle Ages (Princeton, 1984), pp. 200-216. For a study of the early Venetian treaties, with translations of the capitulations between 1482 and 1641, see Hans Theunissen, 'Ottoman-Venetian diplomatics: The 'ahd-names. The historical background and the development of a category of political-commercial instruments together with an annotated edition of a corpus of relevant documents', 2 vols. (unpublished PhD thesis, University of Utrecht, 1991).

Ashtor, Levant trade, pp. 216-269. 
tribute payments. ${ }^{54}$ The peace treaty that was made between Sultan Mehmed II and Venice in 1479 was crucial, as it not only settled frontier disputes but also allowed the Venetians exemption from certain customs duties. Additionally, it also gave them the right to appoint a bailo ${ }^{55}$ in Istanbul, who was to hold internal jurisdiction over the entire Venetian trading community in the Ottoman Empire. Venice was also allowed to extend their protection to foreigners trading under the Venetian flag. ${ }^{56}$ Most of these privileges - tax exemption, internal jurisdiction and the extension of protection - were to become standard in all future European capitulations, although the 1479 text was essentially still a peace treaty.

The privileges established in this treaty were confirmed in 1482 , when Bayazid II rose to the throne. Renewal of treaties following the ascension of a new Ottoman sultan also became commonplace for the European capitulations. Bayazid II's agreement with the Venetians was more extensive, no longer a peace treaty, which is why Alexander de Groot has referred to it as the first set of capitulations (or ahdnames) in the proper sense - a document in which the Ottoman sultan grants fiscal, legal and commercial privileges to a European trading nation..$^{57}$ In 1513, Selīm I renewed the Venetian capitulations, which now included Venetian exemption from the poll tax, the cizye (or haraç),

$54 \quad$ Ibid., pp. $445^{-449 .}$

55 In his article on the development of the capitulations, Alexander de Groot refers to the bailo as holding the same function as those of a consul (p. 577) while also referring to him as an ambassador (p. 588), 'The historical development of the capitulatory regime in the Ottoman Middle East from the fifteenth to the nineteenth centuries', Oriente moderno, nuova serie, 22:3 (2003): pp. 575-604. Maria Pia Pedani also likens the bailo's function to that of the consul but considers him to be more important, 'Venetian consuls in Egypt and Syria in the Ottoman age', Mediterranean world, 18 (2006): pp. 7-8. Pedani mentions the appointment of a bailo as already present in the 1454 treaty.

$5^{6}$ De Groot, 'The historical development', pp. ${ }^{88-589}$. For another general overview, see Viorel Panaite, 'Peace agreements in Ottoman legal and diplomatic view (15th-17th centuries)', in Pax Ottomana: Studies in memoriam Prof. Dr. Nejat Göyünç, ed. Kemal Çiçek (Ankara and Haarlem, 2001), pp. 277-308.

57 De Groot, 'The historical development', pp. 588-59o; see also Maria Pia Pedani, 'Venezia e l'Impero Ottomano: La tentazione dell'impium foedus', in L'Europa e la Serenissima. La svolta del 1509. Nel Vcentenario della battaglia di Agnadello, ed. Giuseppe Gullino (Venezia, 2011), pp. 163-176. European trading nations in the Ottoman Empire, such as the Genoese, had obtained earlier treaties that were also referred to as 'capitulations', but these differed in scope and were different from the later capitulations that came to regulate European presence in the Ottoman Empire in a legally more detailed manner. For these earlier treaties, see Halil İnalcik and Donald Quataert, eds., An economic and social history of the Ottoman Empire, 1300-1914 (Cambridge, 1994), pp. 192-195. 
which was payable by all zimmis. ${ }^{58} \mathrm{~A}$ zimmi was a non-Muslim subject of the Ottoman sultan - a concept that came from 'dhimma', which was 'a contractual bond between Muslim ruler and non-Muslim subject, stipulating the conditions under which certain groups would be allowed to live and practice their religion. ${ }^{59}$ These groups were referred to as the ahl al-dimma, or zimmis (plural). They had to be monotheistic and were subject to pay the cizye tax, while being exempt from the tithe, or zakat. ${ }^{60}$ Exemption from the cizye meant the de facto abolition of an existing rule that said foreigners could legally stay one lunar year in Ottoman lands as müste'min. This was the name for the category of people holding an aman, which was a safe-conduct to travel through the Ottoman Empire. After the lunar year, foreigners had the choice to leave or to become zimmis, thus becoming Ottoman subjects. ${ }^{61}$ Exemption from the cizye tax placed on these zimmis enabled European traders to stay for an indefinite period of time in Ottoman lands without becoming Ottoman subjects.

The conquest of the Mamluk sultanate by Selīm I in 1517 led to a rearrangement of Levantine commercial relationships. The Ottoman sultan now granted Venice a new, separate set of capitulations that dealt with the privileges and tributary payments agreed upon by the Mamluks and Venetians. ${ }^{62}$ The existence of Mamluk treaties with European nations was in some cases an important precedent to the development of later Ottoman capitulations. French communities in Cairo and Alexandria had concluded treaties with the Mamluks, which were mentioned in the Egyptian capitulations Selìm I issued for the French in 1517 , the same year as they were granted to the Venetians. Various stipulations expressed in the document were also present in the first French capitulations for the Ottoman Empire, which dated from 1569 and were granted by Selìm II - these included the legal responsibility of the individual, assistance in salvaging French shipwrecks, execution of wills and settling inheritances. ${ }^{63}$ Such stipulations also resembled the existing Venetian capitulations,

$5^{8}$ De Groot, 'The historical development', p. 591. For the further development of Venetian trade networks in the Levant under Bayazid II's son, Selīm I, see Maria Pia Pedani, 'Venetians in the Levant in the age of Selīm I', in Conquête ottomane de l'Égypte (1517), eds. Benjamin Lellouch and Nicolas Michel (Leiden and Boston, 2012), pp. 99-112.

59 Benjamin Braude, 'Introduction', in Christians \& Jews in the Ottoman Empire. The abridged edition, ed. Benjamin Braude (Boulder, 2014), p. 3. In a way, this can also be considered as a form of protection. Salahi R. Sonyel, 'The protégé system in the Ottoman Empire',Journal of Islamic studies, 2:1 (1991): pp. 56-66.

6o Braude, 'Introduction', pp. 3-7.

61 Van den Boogert, The capitulations, p. 3 .

62 De Groot, 'The historical development', p. 591.

63 The treaty of 1536 between François I and Süleymān the Magnificent was often considered to be the first French ahdnames, but more recent research suggests that this document 
and its eighteen items also included the problem of Mediterranean slavery and exemption from the Ottoman cizye. Additionally, it established customs tariffs and made the presence of an interpreter (dragoman) obligatory in cases where a Frenchman was to appear before a qadi court. The qadis were judges presiding over certain districts, called qada. They had a number of additional duties, which included drafting reports 'on the activities of high-ranking officials, the general situation and the mood of the population.' ${ }^{64}$

The French ahdnames were renewed in 1581, 1597, 1604, 1618, 1673 - the year in which customs tariffs were lowered to the $3 \%$ paid by the English and Dutch - and 1740. ${ }^{65}$ In 1581, the privileges granted to the French were extended to other foreigners operating under the French flag - Venetians, Genoese, English, Portuguese and Catalans, as well as merchants from Ancona and Ragusa. ${ }^{66}$ The possibility to extend protection to traders from other European nations was important, as it influenced the nature of intra-European relationships in the Levant. It led to competition between larger European nations in their struggle for dominance, all attempting to place merchant communities from smaller nations under their protection. It can also be seen as a precursor to the system of Ottoman protégés that was to become so important for Levant trade later on. This 'foreign protection' could be withdrawn in subsequent capitulations, depending on whether the nation of the former protégés had obtained a capitulatory regime of its own. ${ }^{67}$

Murād III granted the English their first capitulations in 1580. These followed earlier Venetian and French capitulations; the English were accorded the same customs tariff of $5 \%$, the right to adjudicate disputes within their own community and exemption from cizye. English traders were allowed to travel and trade throughout the Ottoman Empire. ${ }^{68}$ A renewal of these ahdnames in 1601

never obtained any legal validity. See Viorel Panaite, 'French capitulations and consular jurisdiction in Egypt and Aleppo in the late sixteenth and early seventeenth centuries', in Well-connected domains. Towards an entangled Ottoman history, eds. Pascal W. Firges, Tobias P. Graf, Christian Roth, and Gülay Tulasoğlu (Leiden and Boston, 2014), pp. 71-87. For specific contents on the Egyptian and Ottoman French capitulations, see de Groot, 'The historical development', pp. 595-596.

64 Gy. Káldy Nagy, 'Qadi', in, Judicial practice. Institutions and agents in the Islamic world, ed. Bogaç A. Ergene (Leiden and Boston, 2009), p. 202.

65 De Groot, 'The historical development', pp. 595-6oo. A renewal might contain new articles and clauses and did not occur often. When ascending the throne, every new Ottoman sultan also confirmed the existing capitulations, but these confirmations were not counted as renewals.

66 De Groot, 'The historical development', p. 596.

67 Ibid., p. 597 .

68 For a study of early English-Ottoman relations, including the 1580 capitulations, see Susan Skilliter, William Harborne and the trade with Turkey 1578-1582. A documentary study of the 
lowered the customs tariff to $3 \%$, and the English were allowed to extend their protected status to merchants of certain nations who had not yet concluded capitulations of their own, a right the French already had. This protection also applied to traders coming from Holland, Zeeland, Friesland and Gelderland in the United Provinces and was the outcome of a dispute between the French and English ambassadors, who both tried to exercise influence over the other European trading nations in the Ottoman Empire. ${ }^{69}$ In 16og, the Dutch entered a period of truce with Spain that was to last twelve years. The temporary halt to hostilities with Spain led to an expansion of Dutch trading activities in the Mediterranean to the extent that a special envoy named Cornelis Haga was sent to Istanbul in 1612 to establish official diplomatic relations and commercial privileges. ${ }^{70}$ As a result, the first Dutch ahdnames were granted by Ahmed I the same year (see figure 2). Its fifty-nine articles included exemption from the cizye (article 32) and the establishment of a customs tariff of $3 \%$ (article 12), as well as the right for the Dutch ambassador and consuls to adjudicate intraDutch legal disputes (article 5; see p. 84). The Dutch also received permission to open vice-consulates in 'Alexandria, Tripoli of Syria, the Archipelago, Tunis, Algiers, Cairo and other places' (article 34). ${ }^{71}$ The Dutch capitulations were renewed in 1634 and 1680, while the English ones were renewed in 1601 and 1675. The latter ahdnames resembled the Dutch capitulations of 1612, which

first Anglo-Ottoman relations (Oxford, 1977); see also V.L. Ménage, 'The English capitulation of 1580', International journal of Middle East studies, 12:3 (1980): pp. 373-383.

69 De Groot, 'The historical development', pp. 599-6oo; see also Arthur Leon Horniker, 'Anglo-French rivalry in the Levant from 1583 to 1612', Journal of modern history, 18:4 (1946): pp. 289-305. There is a debate on whether the French capitulations of 1569 formally authorised the French to protect other European traders under their flag, but in practice, both the French and English were indeed doing so, and later, the Dutch did so as well. Fusaro, Political economies, p. 70; Skilliter, William Harborne, pp. 1-3, denied the French were granted such privileges; while Domenico Sella disagreed, Commercio e industrie a Venezia nel secolo XVII (Firenze, 1961), p. 6; see also Hussein I. El-Mudarris and Olivier Salmon, Le consulat de France à Alep au XVIIe siècle. Journal de Louis Gédoyn. Vie de François Picquet. Mémoires de Laurent d'Arvieux (Aleppo, 20o9), pp. 34-35. Alexander de Groot, the authoritative voice on the Dutch capitulations, believes the French capitulations of 1569 indeed enabled the Dutch to trade in the Ottoman Empire while protected under the French flag. De Groot, The Ottoman Empire, p. $5^{2 .}$

70 For Cornelis Haga, see footnote 23 on p. 23.

71 For an extensive overview of the first Dutch capitulations, see de Groot, The Ottoman Empire, which includes an English translation of these capitulations on pp. 138-157. For the article on the vice-consulates, see p. 154. A good account of Cornelis Haga's initial mission as well as the 1612 capitulations, relying extensively on Ottoman sources, is Bülent Arı, 'The first Dutch ambassador in Istanbul: Cornelis Haga and the Dutch capitulations of 1612' (unpublished PhD thesis, Bilkent University, 2003). 


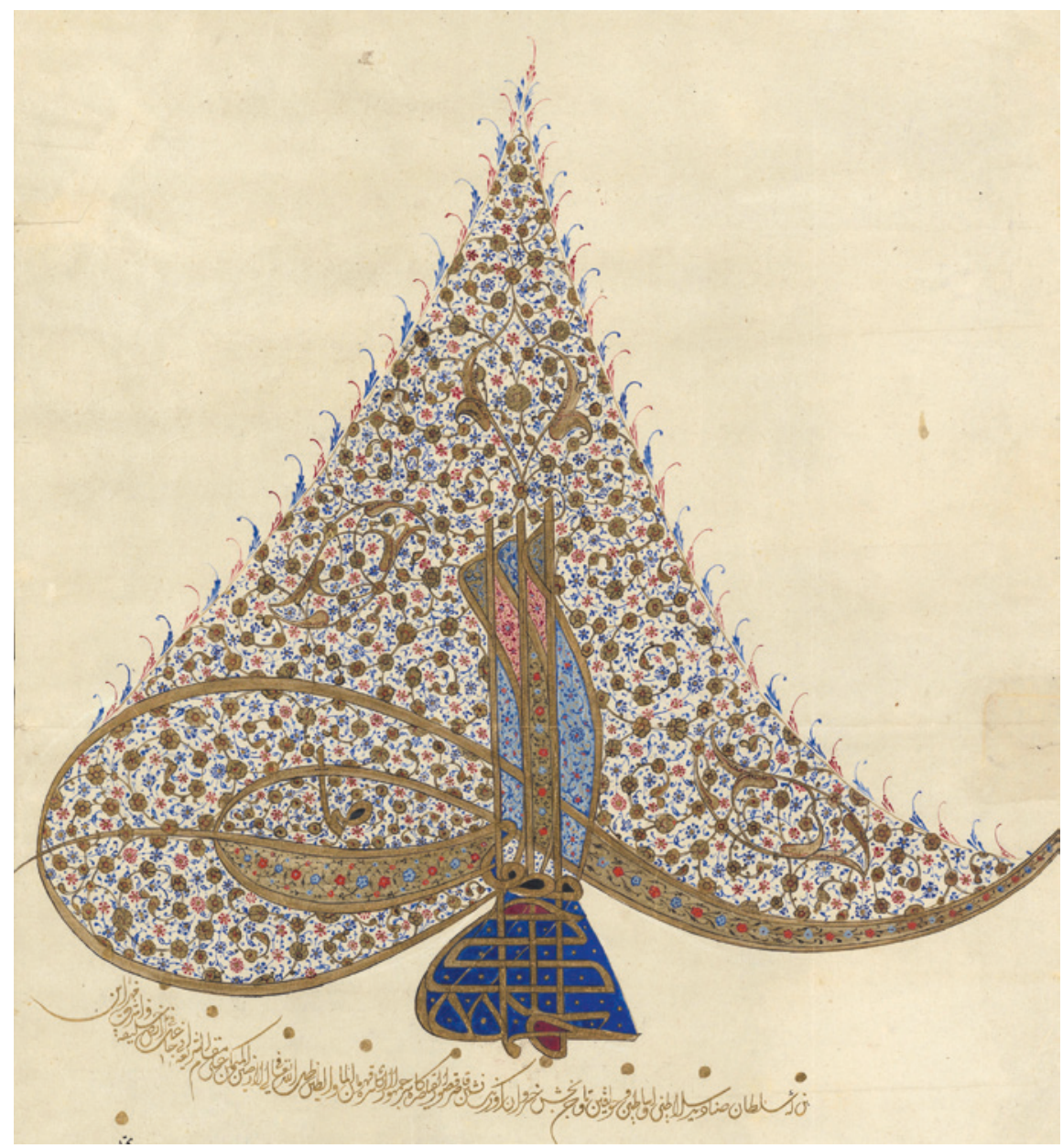

FIGURE 2 Tughra in the capitulations between Sultan Ahmed I and the Republic of the United provinces of 6 July 1612 FROM THE DUTCH NATIONAL ARCHIVES, THE HAGUE (ARCHIVES OF THE STATES GENERAL)

had been generous, and contained seventy-five articles that remained the legal basis for Anglo-Ottoman interaction until $1923 .{ }^{72}$

Interestingly, the English capitulations of 1675 still made a reference to the Anglo-French dispute on who was to protect the Dutch traders, even though the Dutch had obtained their own capitulations in 1612. For de Groot, it was an indication of the conservative nature of these capitulations in later stages, 
as well as of the desire of European nations to hang onto earlier established privileges (in this case protection over the Dutch), even if they were no longer relevant. ${ }^{73}$ In 1694, fourteen years after the last renewal of the Dutch capitulations, the Porte issued a ferman stating that protection of the Dutch flag was extended to the merchant communities of Spain, Portugal, Ancona, Sicily, Florence, Catalonia and Flanders. ${ }^{74}$ This was an important addition, as it covered Sephardi Jews from the Iberian Peninsula, who played an important role as middlemen in Dutch trade with the Levant. ${ }^{75}$ It completed the ascension of the Dutch from being a protected trading nation to a protector, confirming their growing importance throughout the seventeenth century.

Perhaps the most important capitulations granted to a European power were those given to the French in 1740 by Sultan Mahmud I. ${ }^{76}$ They were a recompense for the French assistance given by the Marquis de Villeneuve in concluding the Treaty of Belgrade between the Habsburg and Ottoman Empires a year earlier. With eighty-five articles that dealt with the jurisdiction of French diplomats, artisans, trade and taxes, religious personnel and services, maritime navigation and the problem of the corsairs, the 1740 capitulations were the most extensive set of capitulations issued. Very importantly, they referred to the French king as an equal, and the capitulations became permanent rather than renewable every time a new sultan ascended the throne. ${ }^{77}$ This evolution

73 Ibid., p. 6 o1.

74 Daniel Goffman, 'Izmir: From village to colonial port city', in The Ottoman city between east and west. Aleppo, Izmir, and Istanbul, eds. Edhem Eldem, Daniel Goffman, and Bruce Masters (Cambridge, 1999), p. 111.

75 See pp. $55^{-61}$.

76 It was with the understanding that the 1740 French capitulations were the definitive expression of European privileges as granted by the Ottoman sultan that Thomas-Xavier Bianchi, former translator in Oriental languages for the French king, included a translation of the whole body of French peace treaties and capitulations from 1535 to 1740 as the first part of an appendix to his work on French-Turkish conversation. These translations had been made in 1761 by a Monsieur Deval, first dragoman at the French embassy in Istanbul at the time, and appeared in print as 'Collection complète des capitulations ou traités de paix, de commerce et d'amitié entre la France et la Porte ottomane depuis 1535 (Hég. 942), c'est à dire depuis l'origine des relations entre les deux états, jusques et compris le dernier traité ou convention du 25 novembre $1838^{\prime}$ in T.X. Bianchi, Le nouveau guide de la conversation en français et en turc (Paris, 1852), pp. 247-301, with the Turkish text following thereafter. The translation of the 1740 capitulations can be found on pp. 259-286. Another translation of the 1740 capitulations can be found in Gabriel Effendi Noradounghian, Recueuil d'actes internationaux de l'Empire Ottoman, 1300-1789 (Paris, 1897-1903), 1: pp. 277-3o6.

77 Edhem Eldem, French trade in Istanbul in the eighteenth century (Leiden and Boston, 1999), p. 278. 
can be interpreted as an almost open recognition that the Ottoman-European balance was tipping over in favour of the latter, and the effort can be seen, in a way, as an Ottoman normalisation of relationships along European lines. Another crucial change was that these capitulations formally recognised the principle of the 'most favoured nation' for the first time, which meant that privileges granted in the capitulations to one European nation now also automatically applied to the others. ${ }^{78}$ This principle gave all European trading communities in the Ottoman Empire the same status, and it was an essential characteristic of the Ottoman vision that the various European capitulations were part of one large corpus of codified privileges. It meant that a member of one European trading nation, when defending his privileges towards Ottoman authorities, could invoke the capitulations granted to another nation. ${ }^{79}$

The practice of interconnecting capitulations was not new, but the French ahdnames of 1740 provided Europeans with a definitive version of the 'most favoured nation' principle. Earlier, capitulations for various European nations had influenced one another, as was for instance the case for the English ones of 1675 , which were very similar to the Dutch ones of 1612. Additionally, capitulations for new nations at times referred to existing older ones - the English capitulations of 1580 confirmed privileges for the English that had already been granted to the French, Venetians and Poles. ${ }^{80}$ The first capitulations granted to the Dutch in 1612 included an article stipulating that 'the points written and registered in the capitulation granted to the French and the English are also established in favour of the Dutch.81 Article 29 of the 1740 French capitulations confirms that all privileges given to the Venetians in earlier ahdnames also applied to the French. ${ }^{82}$

By the time the French obtained their 1740 capitulations, the European presence in a number of Ottoman cities had been long and was embedded in the context of social, legal, cultural and commercial norms and institutions, although these had not come about without conflict. The capitulations were just one aspect of this context. While Europeans considered them as acquired privileges, in the sense that they felt the privileges granted in these documents

78 There was only the formal need for European diplomats to obtain official fermans that confirmed these privileges for their own nation. It did give the French a short period of time in which they were the only European nation enjoying new privileges contained in renewed ahdnames. Van den Boogert, The capitulations, p. 25.

79 De Groot, 'The historical development', p. 6o3; see also van den Boogert, The capitulations, pp. 2, 25, 142, and 148.

80 De Groot, 'The historical development', p. 6 o1.

81 The translation can be found in de Groot, The Ottoman Empire, p. 154.

82 Bianchi, Le nouveau guide, p. 268. 
were sacrosanct, the Ottomans increasingly considered them as unilaterally given privileges, which could be revoked or adapted at their own desire. This meant Europeans needed official fermans that confirmed the practical execution of the specific regulations written down in the capitulations. The risk of revocation made Europeans careful not to create precedents that would lead to a retraction of a privilege given to a whole trading nation based on infringements committed by individuals, and protecting the capitulations always remained an important consideration for European diplomats who tried to keep their subjects in line. ${ }^{83}$ The consul or ambassador could be held responsible for the actions of a particular merchant, as is for instance clear from article 69 of the French capitulations of 1740, which stipulated that no Frenchman could be prevented from travelling, as long as the consul or ambassador stood caution for his debts. ${ }^{84}$ It was not uncommon for European diplomats to deny support to individual traders who had put the relationship with the Ottoman rulers at risk through their individual actions, as it might threaten the wellbeing of the whole trading community. An additional problem was that certain articles in the capitulations were open for interpretation, and at times, Ottoman authorities, both in Istanbul and elsewhere, issued fermans that, for Europeans, seemed to contradict the privileges described in the capitulations. Van den Boogert asserted that 'the ahdnames thus were nor immutable, and amendments, clarifications, and, sometimes, revisions, were part of the ongoing process of keeping the texts in tune with reality. The fact that the ahdnames allowed various interpretations was an uncomfortable reality for the Europeans to face. ${ }^{85}$ In short, the capitulations contained a number of fiscal and commercial advantages without which it would have been very difficult, if not impossible, for European traders to establish a profitable business, and the lowering of the customs tariff to $3 \%$ was perhaps the most important commercial measure benefitting the merchants. ${ }^{86} \mathrm{~A}$ second important regulation was exemption from the cizye tax, not so much for financial benefit but because it allowed foreign merchants to remain in the Ottoman Empire for an indefinite amount of time without becoming a zimmi, or Ottoman subject. It was a very important stipulation and one that was generally accepted by Ottoman officials, although it was subject to controversy various times as well, most notoriously in the conflict that arose in the 176 os between Europeans and Greeks

83 For a discussion of the Dutch attitude in this regard, see pp. 287-289.

84 Bianchi, Le nouveau guide, p. 280.

85 Van den Boogert, The capitulations, p. 21.

86 Ibid., pp. 32-33. 
when European traders started to marry Greek women, all zimmis. ${ }^{87}$ The third element that made the capitulations so important for the European presence was the idea of legal autonomy. The ahdnames allowed for a consular apparatus that held jurisdiction over foreign communities. Legal disputes between members of the same European trading community could be adjudicated by the consul of that community. ${ }^{8}$

\subsection{The Dutch Consular System in the Levant}

The ability to exercise legal authority over a foreign trading community can be traced back to the medieval interpretation of consular responsibilities. In the Middle Ages, the office of 'consul' was not clearly defined, but generally, he acted as a mediator between a foreign merchant community and a host nation; the consul was generally a citizen of the city in which the foreign merchant community resided ${ }^{89}$ His role was different from that of the ambassador, who was a political representative. The consul defended commercial interests and was often a trader himself. ${ }^{90}$ The principle that the consul represented merchants instead of states continued to define consular praxis during the early modern period and was of particular relevance to the development of the institution in the Levant. In his seminal article, Niels Steensgaard observed that in the Levant, 'the consuls' primary task was commercial. They were the leaders and representatives of a society of merchants of common origin, the

87 In 1678 , for instance, the Dutch feared that the grand vizir wanted to subject all dragomans, but also Europeans married to Ottoman women, to the cizye. It caused distress, and the Dutch argued that it was against the capitulations. NASG, $\mathrm{N}^{\circ} 6913$ ('Ingekomen ordinaris brieven en stukken van vorstelijke personen, gezanten, enz. betreffende Italië, Turkije en de Barbarijnse staten Algiers, Marokko, Tripoli en Tunis, 1596-1796'), Justinus Colyer to the States General, Istanbul, 18/o1/1678. Olnon argued that European fears were exaggerated. Merlijn Olnon, 'Brought under the law of the land'. The history, demography and geography of crossculturalism in early modern Izmir, and the Köprülü project of 1678 (Leiden, 2013), pp. 206-207; see also his “'A most agreeable and pleasant creature"? Merzifonlu Kara Mustafa Paşa in the correspondence of Justinus Colyer (1668-1682)', Oriente moderno, nuova serie, 22:3 (2003): pp. 649-669.

88 A full understanding of the articles in the capitulations that deal with legal autonomy and litigation are important for the argument of this book and will be discussed in detail in chapter two, pp. 84-89.

89 An extensive bibliography exists on the function of the consul in medieval and early modern times. See for instance the references in Fusaro, Political economies, pp. 159-173. For a historiographical discussion of the Mediterranean context, see the introduction by Arnaud Bartolomei in De l'utilité commerciale des consuls, eds. Bartolomei et al. (Rome and Madrid, 2017), pp. 9-18.

Fusaro, Political economies, pp. 159-16o. 
so-called "nation", ${ }^{91}$ This difference between consul and ambassador can also be observed in the initial lack of diplomatic immunity for the consul, who was subject to local jurisdiction. In the Ottoman context the first mention of consular diplomatic immunity can be found in the English capitulations of 1601 and the French capitulations of $1604 .{ }^{92}$

During the late sixteenth and early seventeenth century, four European states maintained a web of consuls in the Levant - Venice, France, England and the United Provinces. ${ }^{93}$ The oldest consulates were those of Venice and France, which were well-established by the sixteenth century. Venetian consuls were part of the ruling aristocracy, very much tied to the Venetian administration, and not allowed to have commercial interests. The early French consuls in Egypt functioned on the medieval definition of the consulate. This difference between France and Venice might explain the difference in remuneration the Venetian consuls received fixed salaries while their French colleagues were paid out of a consular fee, a tax paid by the merchants the consuls were representing. ${ }^{94}$ The Dutch opted for the French model of remuneration on the basis of a tax that also was intended to cover consular expenses - a choice that was, according to Steensgaard, 'unsuccessful in most places but disastrous in the Levant'. 95 Throughout the seventeenth century, this choice led to a great deal of conflict between consuls and the merchants they represented. ${ }^{96}$ The legislation issued by the States General throughout the seventeenth century aimed to quell conflicts between consuls and merchants but, at the same time, became

91 Niels Steensgaard, 'Consuls and nations in the Levant from 1570 to 1650', The Scandinavian economic history review, 15 (1967): pp. 14-15.

92 Fusaro, Political economies, p. 16o; and Steensgaard, 'Consuls and nations', p. 18.

93 Steensgaard, 'Consuls and nations'. For an early history of the Venetian consuls in the eastern Mediterranean, see Benoît Maréchaux, 'Consuls vénitiens en Méditerranée orientale (1575-1645)', in Los cónsules de extranjeros en la Edad Moderna y a principios de la Edad Contemporánea, eds. M. Aglietti, M. Herrero Sánchez, and F. Zamora Rodríguez (Madrid, 2013), pp. 145-158. For France, see Géraud Poumarède, 'Naissance d'une institution royale: Les consuls de la nation française en Levant et en Barbarie aux XVI e et XVII ${ }^{\mathrm{e}}$ siècles', Annuaire-bulletin de la Société de l'Histoire de France (2001): pp. 65-128.

94 Steensgaard, 'Consuls and nations'.

95 Ibid., p. 32. This was because the expenses were very unpredictable in the Levantine context. For a general overview of the establishment of Dutch consulates throughout the Levant, see Jonathan Israel, 'The Dutch merchant colonies in the Mediterranean during the seventeenth century', Renaissance and modern studies, 30 (1986): pp. 87-108.

96 Consular correspondence preserved in the archives of the Directorate of Levant Trade contains several references to quarrels between consuls and merchants; see also Fusaro, Political economies, pp. 159-173. Several examples in the Dutch context will be discussed below; see pp. 49-52, 91-95 and 100-101. 
the legal foundation defining the mutual rights between consuls and traders for the remainder of the early modern period.

Van den Boogert has remarked that the text of the first Dutch capitulations of 1612 'seems to take the existence of consuls for granted'. ${ }^{97}$ The first stronghold of Dutch Levant trade was a small trading contingent that had established itself in Aleppo, in present-day Syria. In 1607, a man from Dordrecht named Arnoult de la Valée was asked by Dutch merchants there to act as their consul. His salary would be paid by the merchants. ${ }^{98}$ De la Valée's arrival in Aleppo was the first indication of a Dutch consulate in the Ottoman Empire, and it seems to have been on the basis of the medieval interpretation of what the consul was: 'the elected leader of a specific group of merchants, who often all came from one location, residing in a particular place abroad' ${ }^{99}$ De la Valée was not appointed by the States General but worked for the Dutch traders of Aleppo. ${ }^{100}$ The choice for Aleppo was logical, as it was an important centre of trade and one of the stops of the silk caravan. ${ }^{101}$ The Dutch trading community continued to expand, and it grew from two or three firms in 1604 to twenty in 1615 , holding a share of the city's trade that was twice as large as what the English held. ${ }^{102}$

By this time, the Dutch consular system had undergone important changes following Cornelis Haga's arrival in Istanbul in March 1612. This was the period before the establishment of the Directorate of Levant Trade in Amsterdam, and the ambassador in Istanbul appointed consuls directly. Haga was involved in the early appointments of consuls on the Greek island of Chios and on Cyprus. ${ }^{103}$ In Aleppo, the most important commercial centre for Dutch Levant trade, Cornelis Pauw was appointed consul in 1612. ${ }^{104}$

97 Maurits van den Boogert, 'Negotiating foreignness in the Ottoman Empire: The legal complications of cosmopolitanism in the eighteenth century', in Exploring the Dutch Empire. Agents, networks and institutions, 1600-2000, eds. Catia Antunes and Jos Gommans (London, 2015), p. 29.

98 Schutte, Repertorium der Nederlandse vertegenwoordigers, p. 349.

99 Van den Boogert, 'Negotiating foreignness', p. 29. The first English consulates seem to have been considered the same way.

100 Kersten and van der Zwan, 'The Dutch consular service', p. 276.

101 For the importance of Aleppo as a trading centre for western Europeans, see Bruce Masters, The origins of western economic dominance in the Middle East: Mercantilism and the Islamic economy in Aleppo, 1600-1750 (New York, 1988); 'Aleppo: The Ottoman Empire's caravan city', in The Ottoman city, eds. Edhem Eldem et al., pp. 17-78.

102 Israel, 'The Dutch merchant colonies', pp. 91-92.

103 Schutte, Repertorium der Nederlandse vertegenwoordigers, pp. 346-347. For Haga's tenure as ambassador, see ibid., pp. 302-306.

104 Ibid., p. 349. 
Pauw had been part of Haga's entourage in Istanbul, and his father Reynier had been a very important man in Amsterdam, a merchant who had been burgomaster, alderman, commissioner of the exchange bank and director of the Dutch East India Company. ${ }^{105}$ Pauw was very important from an institutional point of view. While his predecessor had been in the private service of a group of merchants, Pauw was officially appointed by the States General. His appointment was confirmed by a regulation published by the States General in December 1612. It was the first time that legislation aiming to regulate consular appointments in the Levant was published. A first regulation instructed the head consul in Aleppo as well as the consuls in other quarters to deal with the inheritances of those who had died in their legal territory but had left no will. The consul had to make an inventory, register all the goods and inform the relatives. ${ }^{106} \mathrm{~A}$ second regulation issued the same day authorised the head consul in Aleppo as well as the other consuls in the Levant to issue notarial acts with full legal powers, such as contracts, registrations of commercial transactions, wills, certifications and other documents at the demand of merchants, factors, skippers and all other individuals belonging to the United Provinces. These acts had to be drafted in the presence of witnesses. ${ }^{107}$

The right to levy consular and ambassadorial taxes was only codified in a regulation from 1615 - while Haga was still ambassador in Istanbul and Pauw was still consul in Aleppo. ${ }^{108}$ The regulation stipulated a tax of $1.5 \%$ on all cash and goods that arrived in the Levant on behalf of Dutch merchants, which would be used to pay the salary of the ambassador in Istanbul, and a tax of $2 \%$ on the same commodities to pay for the salaries of the consuls. The salary of the consul in Cyprus, which amounted to 6,ooo guilders per year and was paid by the Dutch merchant community there, was also subject to this new

105 Ibid., p. 11 and pp. 175-177.

106 Cau, Groot placaet-boeck, 2: pp. 1331-1332, 'Acte voor de consuls in de Levanten, noopende 't registereren der goederen vande overledene aldaer', o8/12/1612; see also van den Boogert, The capitulations, pp. 40-41.

107 Cau, Groot placaet-boeck, 2: pp. 1333-1334, 'Acte, waar by den secretaris vanden hooftconsul tot Aleppo, ende de andere secretarisen vande consuls inde andere quartieren van Levante gelast wert, te passeren alle contracten, compromissen, certificatien, \&c. ten behoeve vande coopluyden, facteurs, schipperen, ende andere negotianten ende particuliere persoonen', $08 / 12 / 1612$.

108 Ibid., pp. 1333-1336, 'Acte, waer by gheconsenteert wort ten behoeve vanden orateur tot Constantinopolen, ende consul van Aleppo, te lichten van alle de goederen inde Levante gebracht wordende anderhalf ende twee ten hondert, met authoriqatie tot het lichten der selver penningen, \&c., o6/o6/1615. For Cyprus, see Schutte, Repertorium der Nederlandse vertegenwoordigers, p. 347 . 
regulation. To avoid fraud, merchants and skippers had to promise honesty about the goods they registered and shipping papers had to be shown to the consul. ${ }^{109}$ Nine months later, additional legislation regulated the adjudicating powers of the consul in Aleppo. ${ }^{110}$

These regulations were accompanied by an expansion of the consular apparatus in the Mediterranean and the Levant. Between 1612 and 1618, the States General appointed consuls in Livorno, Venice, Genoa, Larnaca, Tunis, Algiers, Zante and Izmir. ${ }^{111}$ By 165 , there were nine Dutch (vice-)consulates in the Levant, as well as three in Salé, Tunis and Algiers. ${ }^{12}$ By 1700 the number of Dutch (vice-)consulates was lower, only eight, but by 1750 there were twentytwo. By 1800 the number had fallen to fourteen. ${ }^{113}$ The consuls were officially appointed by the States General, but after 1625 , they had to communicate with the Directorate of Levant Trade. There was thus a separation of the political appointment of the consuls by the States General and the consular accountability to the Directorate of Levant Trade. This system reflects the medieval distinction between the ambassador as a political state representative and the consul as a protector of the interests of merchants. ${ }^{114}$ It was more explicit in the Dutch case because of the decentralised nature of the state apparatus and

109 Cau, Groot placaet-boeck, 2: pp. 1333-1336, 'Acte, waer by gheconsenteert wort ten behoeve vanden orateur tot Constantinopolen', o6/o6/1615.

110 See pp. 93-94.

111 Israel, 'The Dutch merchant colonies'; and Steensgaard, 'Consuls and nations'. The end of the Eighty Years' War in 1648 was followed by Dutch consular appointments in Messina, Nice, Villafranca, Puglia, Naples and Ancona. See Tessa Agterhuis, 'Tot dienst, voordeel ende proffijt van de coopluyden ende schipperen van dese landen. Nederlandse consuls in Italiaanse havens, 1612-1672' (unpublished MA thesis, Leiden University, 2013), p. 12. Several of the early consuls in the Levant and North Africa, such as Lamberto Verhaer, the second consul in Tunis, had been part of Haga's entourage on his mission to Istanbul in 1612. See Schutte, Repertorium der Nederlandse vertegenwoordigers, p. 370.

112 For Algiers, see Gerard van Krieken, Kapers en kooplieden. De betrekkingen tussen Algiers en Nederland (Amsterdam, 1999); see also Schutte, Repertorium der Nederlandse vertegenwoordigers, pp. $368-38$ o for the different representatives in Tunis and Algiers, which started with Wijnant de Keyser's appointment in 1616. For Morocco, see ibid., pp. 381-388. For an analysis of Dutch diplomatic activities in North Africa, see Erica Heinsen-Roach, Consuls and captives. Dutch-North African diplomacy in the early modern Mediterranean (Rochester, NY and Suffolk, 2019).

113 Van den Boogert, 'Negotiating foreignness', p. 30. Vice-consulates were established in places considered less important, and they were considered as more informal than consulates. Steensgaard, 'Consuls and nations', p. 25.

114 Maria Fusaro remarked that this 'political asymmetry' was inherent to the medieval interpretation of the consulate. Fusaro, Political economies, p. 16o. 
existing competition between different cities and provinces. ${ }^{115}$ Merchants were fully aware of the distinctive responsibilities of Dutch diplomats, and as early as 1612, Levant traders argued that the ambassador was serving the interests of the Dutch state (the United Provinces) and the consuls those of Dutch trade. ${ }^{116}$

The role played by Dutch urban governments and institutions makes it complicated to argue that consular appointments were part of a strategy to foster Dutch commercial interests rather than the particular interests of merchant communities. Maartje van Gelder argued that it is certain that there was an interplay between Dutch merchant communities and official Dutch representatives, with some overlap in personnel, and this interplay could foster particular interests, as well as national interest, without turning local Mediterranean Dutch trading communities into extensions of the United Provinces. ${ }^{117}$ In the eighteenth century, the idea of 'national' interest became more central. In a memoir on Dutch trade written in 1754, Elbert de Hochepied, Dutch ambassador in Istanbul, discussed a reorganisation of Levant trade to bring back former glory to the homeland ('la patrie'). ${ }^{118}$ National interest started to figure prominently in discourse used by consuls in their letters to the Directorate of Levant Trade. At the same time, cities continued to play their role. Dutch consuls in the Mediterranean often had Amsterdam origins, and the States General had specifically transferred the responsibility of maintaining a diplomatic network in the Mediterranean to the Amsterdam Levant Directorate, the biggest of all the directorates. ${ }^{119}$

Archival material does not allow for a hypothesis that conflict between consuls and merchants can be explained by strife between factions coming from different Dutch cities. Reasons for the recurrent conflicts in the seventeenth century were personal and financial. From an early stage onwards, merchants attempted to avoid paying consular duties, and sometimes Dutch ships sailed

115 Oscar Gelderblom made a convincing argument for change in the Dutch institutions established to foster international commerce as driven by competition between cities. Gelderblom, Cities of commerce.

116 A.T. van Deursen, ed., Resolutiën der Staten-Generaal. Nieuwe reeks 1610-1670 (The Hague, 1971), 1: p. 793, Meeting States General o6/12/1612.

117 Van Gelder, Trading places, pp. 159-168.

118 NA, $\mathrm{N}^{\circ}$ 2.21.006.46 ('Archief van F.G. Baron van Dedem van de Gelder'), $\mathrm{N}_{2}{ }_{2}$ ('Mémoire pour le commerce d'Hollande en Levant. Composé par J. Chevrier, sécretaire de S.E. Monseigneur le Baron de Hochepied, ambassadeur d'Hollande à Constantinople, fait et écrit sur les idées de mondit seigneur et par son ordre', 1754).

119 G.T.H.C. Pieck, 'Francesco Gallacini, Florentijns koopman te Rotterdam 1647-1705', Rotterdamsch jaarboekje, 8 (1980): p. 207; see also the biographies of consuls in Schutte, Repertorium der Nederlandse vertegenwoordigers, passim. 
under French, Venetian or English flags in order to avoid the higher Dutch duties. ${ }^{120}$ Merchants felt taxes were too high, while the consuls felt they were not sufficient to cover both their salaries and the expenses they incurred when protecting the commercial interests of the Dutch merchants under their jurisdiction. The States General and the Directorate of Levant Trade concentrated on new regulations aimed at settling issues of taxes and remuneration, and they attempted to delineate clear rules on consular wages and expenses, particularly in Izmir, which had become the location of the most important Dutch trading community by the middle of the seventeenth century. A new regulation was published in October 1675 that aimed to settle this long-standing issue. The salaries of the ambassador in Istanbul at the time, Justinus Colyer, and the consul in Izmir, Jacob van Dam, were set at a fixed rate by law. The ambassador would receive 9,500 guilders a year as payment, as well as an additional 12,500 guilders every six months that came from the ambassadorial taxes on trade. The consul in Izmir would enjoy a remuneration of 10,000 guilders per year, funded by consular taxes on the Levant trade. ${ }^{121}$ These sums were not only meant as salary but also had to cover household expenses as well as the salaries of other officials, such as the treasurer and chancellor, the chaplain, dragomans and janissaries. ${ }^{122} \mathrm{~A}$ special administration needed to be

120 Mehmet Bulut, 'The role of Ottomans and Dutch in the commercial integration between the Levant and the Atlantic in the 17th century',Journal of the economic \& social history of the Orient, 45:2 (2002): pp. 211-212.

121 Cornelis Cau, Groot placaet-boeck inhoudende de placaeten, ende ordonnantien vande hoog mog. heeren Staten Generael der Vereenighde Nederlanden, ende van de groot mog. heeren Staten van Holland ende West-Vriesland; mitsgaders van de ed. mog. heeren Staten van Zeelandt (The Hague, 1683), 3: p. 311, 'Extract uyt de resolutien van de Staten Generael der Vereenighde Nederlanden; reglement voor den resident tot Constantinopelen, Consul tot Smirna, ende Nederlantsche natie in de Levant', o7/10/1675. This followed earlier iterations of the same regulation published in April of the same year. Heeringa and Nanninga, Bronnen tot de geschiedenis, 2: pp. 204-207, 'Resolutie van de Staten-Generaal betreffende het reglement voor den resident te Constantinopel en den consul te Smirna', 12/o4/ 1675 .

122 The janissaries were enslaved soldiers, taken through the devşirme system, who had originally been serving as bodyguards for the sultan but who later became a wellrespected and much-envied part of the Ottoman army, and a faction to be reckoned with within Ottoman political structures. See Gilles Veinstein, 'On the Ottoman janissaries (fourteenth-nineteenth centuries)', in A comparative study of military labour (1500-200o), ed. Erik-Jan Zürcher (Amsterdam, 2013), pp. 115-134; see also Gülay Yılmaz, 'The economic and social roles of janissaries in a 17th century Ottoman city: The case of Istanbul' (unpublished $\mathrm{PhD}$ thesis, McGill University, 2011). Small contingents of janissaries were employed by European diplomats to ensure their physical protection. 
kept in which all the duties on merchandise were to be registered and controlled by the treasurer. ${ }^{123}$ Later, in 1724 , the remuneration of the consul would be reduced from 10,000 to 6 , ooo guilders. ${ }^{124}$

The treasurer was a new post installed in 1675 to collect the ambassadorial and consular duties. ${ }^{125}$ Along with the collection of these duties, the treasurer was also responsible for the arrangement of gifts to Ottoman officials and for all bookkeeping related to the consulate and the trading community as a whole. The consular accounts were also monitored by assessors, merchants elected by the community who also fulfilled crucial tasks in adjudication. ${ }^{126}$ Officially, the treasurer was not allowed to trade - the exception was the treasurer in Aleppo. In 1729, the Dutch ambassador in Istanbul, Cornelis Calkoen, wrote a letter to a member of the illustrious Fagel family in which he suggested that the treasurers should be allowed to be merchants, but that the office should be rotated yearly, as was customary amongst the consulates of other European nations. ${ }^{127}$ Calkoen felt this measure would prevent envy towards the treasurer, as the merchants were obliged to give accounts of their imports and exports to him, information he could exploit to gain an unfair advantage in trade. ${ }^{128}$ Calkoen's suggestion was not followed, perhaps because the conflict of interest was still

123 Cau, Groot placaet-boeck, 3: p. 311, 'Extract uyt de resolutien van de Staten Generael der Vereenighde Nederlanden; Reglement voor den resident tot Constantinopelen, consul tot Smirna, ende Nederlantsche natie in de Levant', o7/10/1675.

124 Isaac Scheltus, Groot placaatboek, vervattende de placaaten, ordonnantien en edicten van de hoog mog. heeren Staten Generaal der Vereenigde Nederlanden; en van de edele groot mog. Heeren Staaten van Holland en Westvriesland mitsgaders van de edele mog. heeren Staaten van Zeeland (Amsterdam, 1795 [The Hague, 1746]), 6: p. 289, 'Resolutie, het tractement van den consul te Smirna van tien duisend guldens op ses duisend guldens vermindert', $28 / 01 / 1724$.

125 The first treasurer was Jacob van der Merct, a commissioner for the Directorate of Levant Trade who had been stationed in Texel, and who arrived in Izmir in 1676. Schutte, Repertorium der Nederlandse vertegenwoordigers, p. 343.

126 See pp. 91 and $94-95$.

127 It is not immediately clear to whom the letter was addressed. Members of the Fagel family, originally from Lokeren in Flanders, became clerks at the States General and attorneys and councillors at the Hof van Holland. Nieuw Nederlandsch biografisch woordenboek, eds. P.C. Molhuysen and P.J. Blok (Leiden, 1914), 3: pp. 385-394. At the time of writing, Cornelis Fagel was a councillor at the Hof van Holland, his son Hendrik was an official at the States General, as well as his brother François, who was a clerk there. As this and other letters sent by the ambassador to Fagel were kept in the archives of the States General, this letter - and others that will be mentioned later - must have been sent to either Hendrik or François, and thus they are addressed the States General.

128 Heeringa and Nanninga, Bronnen tot de geschiedenis, 3: pp. 21-24, Ambassador Cornelis Calkoen to Fagel, Istanbul, 30/11/1729. 
considered too large, and the office of treasurer was only occupied by merchants in 1765 and 1766, by William Enslie and Daniel Fremeaux respectively, but both stints were only temporary replacements. ${ }^{129}$ The responsibilities of the chancellor were crucial to the functioning of the consulate. More so than the office of treasurer, the chancellor had a full-time job; he was responsible for the drafting and registration of official documents at the chancery and the communication with other consulates and litigating parties in a trial. Because he did not handle the consulate's finances, he was allowed to trade. ${ }^{130}$

Consular and ambassadorial duties were put at $1.5 \%$ of the value of all imported and exported Levantine goods handled by Dutch merchants, but these were raised to $2 \%$ in 1692 . Dutch traders shipping on foreign vessels had to pay a consular fee that was twice as high, although in the early eighteenth century Dutch merchants from Izmir demanded for that to be abolished, something which was done in $1750 .{ }^{131}$ The concrete execution of the 1675 regulation was the subject of ongoing dispute, not only because the quarrels in Izmir between traders and consul continued but also because the regulation had first been drafted on the initiative of the Directorates of Levant Trade in Leiden and Rotterdam without prior knowledge of the more powerful directorate in Amsterdam. ${ }^{132}$ The Amsterdam Directorate agreed but decided to draft a form, together with their colleagues in Leiden, that specified in twenty-two articles all the practical procedures related to remunerations for the ambassador in Istanbul and consul in Izmir and the levying of the consular and ambassadorial taxes on merchandise. This document also included texts for an oath demanded from the treasurers, who had to promise to register the taxes honestly and not to favour any particular merchant, as well as for the oath demanded from merchants and maritime personnel, in which they promised

129 Schutte, Repertorium der Nederlandse vertegenwoordigers, p. 344. Treasurers in Izmir had sometimes occupied administrative functions at other Dutch diplomatic institutions, such as Coenraad Schutz, who had been secretary (1752-1766) and chancellor (17561766) in Istanbul before becoming treasurer in Izmir, a post he held until 1802. Schutte, Repertorium der Nederlandse vertegenwoordigers, pp. 311 and 344.

130 Johan Frederik Mann, chancellor between $175^{1}$ and 1774, appears as a trader on the list of imports and exports of Dutch firms in Izmir between 1753 and 1765 . See Heeringa and Nanninga, Bronnen tot de geschiedenis, 3: pp. 778-783, 'De Nederlandsche handelshuizen te Smirna en de waarde van hun invoer en hun uitvoer met Nederlandsche schepen in de periode 15 juli 1753-31 december 1765'. On Mann, see Schutte, Repertorium der Nederlandse vertegenwoordigers, p. 342 .

131 Hakkı Kadı, Ottoman and Dutch merchants, pp. 150-151.

132 For the quarrels in Izmir, see pp. 49-52. A first resolution to settle the diplomatic remunerations had already been drafted in April 1675. See Heeringa and Nanninga, Bronnen tot de geschiedenis, 2: pp. 204-207. 
to register their merchandise honestly and not commit fraud. The document was sent to the burgomasters of Amsterdam in January 1676 and to the States General in March. Shortly after their approval, copies were sent to the ambassador in Istanbul and the consul in Izmir with instructions that all had to observe the regulations stipulated in the twenty-two articles. ${ }^{133}$ It would take another decade before the structural disputes in Izmir between consul and merchants were settled for good.

\section{The Dutch Consulate of Izmir}

3.1

\section{The Evolution towards Stability}

Aleppo in present-day Syria was the city with the first Dutch consul and with the most important Dutch trading community in the Levant. It is therefore not surprising that the first attempts to build a legislative framework around the Dutch Levantine consular system focussed on the situation in Aleppo. But by the end of the second decade of the seventeenth century, a few other consulates had been established as well. The most important one quickly turned out to be the consulate in Izmir. The first Dutch consul there was a Venetian named Nicolò Orlando, who was consul between 1618 and 1633. Before him, the English consul had acted as Dutch vice-consul. Orlando was succeeded by a Greek named Duca di Giovanni, who was consul between 1635 and $1657 \cdot{ }^{134}$ By the middle of the seventeenth century, Izmir had replaced Aleppo as the most important trading centre for Dutch traders in the Ottoman Empire. In their search for commercially viable cotton, merchants were looking for a port city with few regulations, and the choice fell on Izmir. ${ }^{135}$ Izmir's growing importance came at the detriment of the Dutch community in Aleppo. Only one Dutch merchant was trading there during the 1640s, and for extended periods of time, there was no Dutch consul active in Aleppo. In 1684, a Dutch trader

\footnotetext{
133 Heeringa and Nanninga, Bronnen tot de geschiedenis, 2: pp. 207-217, 'Formulier, waernaer ende volgens hetwelcke den heer resident tot Constantinopelen, consul tot Smirna, aengestelt bij de H.M. heeren Staten-Generael der Vereenigde Nederlanden, en de gantsche Nederlantsche natie in de Levant residerende, respective, haer sullen hebben te reguleren omtrent den ontfanck en distributie van de ambassaet- en consulaetrechten', 1676.

134 Schutte, Repertorium der Nederlandse vertegenwoordigers, pp. 331-332. De Groot gives 1614-1629 as the period of Orlandi's consulship and 1630-1633 as the period when his brother Julio acted as Dutch consul, The Ottoman Empire, p. 129.

135 Elena Frangakis-Syrett, The commerce of Smyrna in the eighteenth century (1700-1820) (Athens, 1992), p. 24; see also Goffman, 'Izmir'; as well as his Izmir and the Levantine world, 1550-1650 (Seattle, 1990) for an analysis of this development.
} 
named Coenraet Calckberner addressed the Directorate of Levant Trade about the difficulties the Dutch community in Aleppo were experiencing because of the growing importance of Izmir. ${ }^{136}$

It is perhaps Izmir's rapid rise that made the States General decide to appoint a Dutchman as consul after di Giovanni's tenure, particularly as the Dutch traders in Izmir had already made such a request in 1653. The States of Holland proposed Michel du Mortier, one of two candidates selected by the Directorate of Levant Trade in Amsterdam. Du Mortier was a citizen of Leiden who was experienced in trade in the Levant. The States General accepted, and du Mortier was sent to Izmir, where he quickly attempted to enforce stricter control over the payment of consular duties while also claiming larger financial contributions from the merchants to the funds to purchase gifts for Ottoman officials. Unsurprisingly, the merchant community rebelled against him, leading to his dismissal in 1660 and the temporary return of di Giovanni. ${ }^{137}$

Dutch consuls and ambassadors in the Levant were not allowed to engage in commercial activities, but their income relied mainly on taxes paid by subjects whose commercial interests they represented. When quarrels about these taxes reached a zenith in 1658 , the suggestion was made that the next appointment for consul should fall upon a merchant and not a legal scholar, as had hitherto been the case. Allowing a consul to trade would mean that he no longer depended on Dutch merchants for his salary, a dependence that had, according to a 1658 memorandum, led to jealousy on the part of the consul. The authors of the memorandum hoped that this change in policy would not only bring about a more harmonious relationship in Izmir between the consul and the merchants but also put a man in place who possessed knowledge and experience more apt for dealing with the demands of the Dutch trading community in Izmir. ${ }^{138}$

The traditional qualities required of consuls up to that moment were scholarly and not mercantile, and they included an acquaintance with Latin and the laws of the United Provinces. These were considered of lesser importance

$136 \mathrm{NALH}$, 'Directie Amsterdam', $\mathrm{N}^{\circ} 161$ ('Brieven van de vertegenwoordigers te Constantinopel, van de consuls en andere ambtenaren in de Levant en langs de Middellandse Zee. Aleppo en Cyprus', 1627-1826), Letter Coenraet Calckberner to Amsterdam Directorate of Levant Trade, Aleppo, 24/11/1684. Calckberner, from Amsterdam, was consul of Aleppo between 1689 and 1694. Schutte, Repertorium der Nederlandse vertegenwoordigers, pp. 351-352.

137 Heeringa and Nanninga, Bronnen tot de geschiedenis, 1: pp. 613-616, Directorate of Levant Trade to the States General, o6/o8/1653. For more on both consuls, see Schutte, Repertorium der Nederlandse vertegenwoordigers, pp. 331-332.

138 Heeringa and Nanninga, Bronnen tot de geschiedenis, 1: pp. 1100-1102, 'Memorie en particuliere bedenkingen over de saken van Levanten', ca. 1658 . 
in the Levant, while knowledge of Spanish and Italian, common trading languages in the Mediterranean, was deemed far more important. ${ }^{139}$ The suggestions made in the memorandum were not implemented, and for the remainder of the early modern period, the Dutch merchant community of Izmir continued to fall under the jurisdiction of men who were well versed in Latin and the laws of the Dutch Republic.

Even though the recommendations made in the memorandum were not implemented, the States General did issue a general regulation for Dutch consuls in the Mediterranean as well as another regulation that specifically applied to consuls active in the Ottoman Empire on the same day in July 1658. In its Ottoman regulation, the States General warned the merchants not to commit fraud in their declarations of goods subject to the payment of consular taxes $-1 \%$ on imported and exported goods that passed through Izmir. ${ }^{140}$ The States General also hoped to end existing quarrels between the Dutch merchants in Izmir and their consul in the hopes that both parties would be thus able to 'preserve the honour of the nation and the prosperity of trade through a reciprocal harmony at all moments.' ${ }^{141}$ In spite of these measures, the relationship between consul and traders in Izmir remained difficult until the end of the seventeenth century. After di Giovanni's short return, du Mortier was finally replaced by Gerard Smits, an old man who had great difficulties establishing his authority. His turn to become disputed by the traders came quickly, and he was dismissed in 1668 after complaints that he had raised unauthorised taxes for his own benefit. The merchants also accused him of neglecting his duty to provide Ottoman dignitaries with gifts. ${ }^{142} \mathrm{He}$ was replaced by Jacob

139 On the use of lingua franca in the Mediterranean, see Eric R. Dursteler, 'Language and identity in the early modern Mediterranean', in Mediterranean identities in the premodern era: Entrepôts, islands, empires, eds. John Watkins and Kathryn L. Reyerson (Farnham and Burlington, 2014), pp. 35-52; and 'Speaking in tongues: Language and communication in the early modern Mediterranean', Past \& present, 217 (2012): pp. 47-77.

140 The general Mediterranean resolution can be found in Cau, Groot placaet-boeck, 2: pp. 1343-1344, 'Extract uyt 't register vande hoogh mogende heeren Staten Generael der Vereenighde Nederlanden, behelsende generael reglement voor de Nederlantsche consuls', 24/07/1658. The text for the Ottoman resolution can be found in Heeringa and Nanninga, Bronnen tot de geschiedenis, 2: pp. 156-158, 'Resolutie der Staten-Generaal tot nederlegging der geschillen in Smyrna', 24/07/1658.

141 Ibid., p. 157, '[...] door een overeenstemmende harmonie de eere van de natie ende den fleur van de negotie allenthalven te conserveren'.

142 For Smit's tenure, see Schutte, Repertorium der Nederlandse vertegenwoordigers, p. 332. On the dispute between him and the Directorate of Levant Trade, see NASG, $\mathrm{N}^{\circ}{ }_{125} 5^{0.123}$ ('Stukken betreffende de geschillen tussen de Directeuren van de Levantse Handel en Gerardus Smits, gewezen consul te Smyrna, over nalatigheid in zijn functie, 1666'). 
van Dam, who did not want to suffer the same fate as his predecessors. He immediately asserted his authority, and in the end, it worked, as he stayed consul for almost twenty years. ${ }^{143}$ One of his first decisions was to ban Dutch merchants from certain meetings, restricting them to himself and those merchants who held an official position. He also tried to stop one of the most common abuses: avoiding the payment of consular and ambassadorial duties. Van Dam felt his income was not high enough, particularly considering his expenses - for instance, purchasing gifts for Ottoman officials. The merchants in turn were quick to complain about the consul's excessive use of authority, which included the arrest of fraudulent traders. ${ }^{144}$

The atmosphere was already heated when the consul joined the Dutch ambassador on a trip to meet the sultan in Edirne at the end of 1668. The Dutch trading community in Izmir was instructed to cover the trip's expenses through a loan. Later, both the States General and the Directorate of Levant Trade refused to pay for the trip, and the Dutch traders in Izmir asked for exorbitant interest fees, complaining that nothing had been asked of their colleagues in Istanbul. This particular expense account was to cause trouble between the consul and Dutch merchants in Izmir for years to come. Between 1668 and 1672 , both sides petitioned the Directorate of Levant Trade and the States of Holland to act, without much result. In a later phase, between 1672 and 1675 , some traders tried to get the consul dismissed. ${ }^{145}$ In those years, the English consul in Izmir mediated twice, but his efforts did not bring about any long-lasting solution. The authorities in the United Provinces recognised the gravity of the problem, for which they held the consul partially responsible. Nobody had any doubts that Dutch merchants avoided full payment of due taxes, out of which the consul gained his income, but it was also felt that the consul acted too harshly at times, which damaged Dutch commercial interests in the Levant. Several merchants complained to the burgomasters in

143 On the career of Jacob van Dam, see Schutte, Repertorium der Nederlandse vertegenwoordigers, pp. 332-334; see also Thierry Allain, 'Linformation comme instrument de combat. Le consulat de Jacob van Dam à Smyrne (1668-1688)', in Les consuls en Méditerranée, agents d'information XVIe-XXe siècle, ed. Silvia Marzagalli (Paris, 2015), pp. 81-97.

144 For an extensive analysis of these conflicts and the main protagonists, including a summary of the problems in Izmir before van Dam's time, see W.E. van Dam van Isselt, 'Eenige lotgevallen van Jacob Van Dam, consul te Smirna van 1668-1688', in Bijdragen voor vaderlandsche geschiedenis en oudheidkunde, ed. P.J. Blok, 4th series, part 6 (The Hague, 1907), pp. 78-136; and 'De klachten, tusschen 1672 en 1675 ingebracht tegen Jacob van Dam, consul te Smirna (1668-1688)', in Bijdragen voor vaderlandsche geschiedenis en oudheidkunde, ed. P.J. Blok, 4th series, part 6 (The Hague, 1907), pp. 277-351.

145 Van Dam van Isselt, 'De klachten'. 
Amsterdam about the 'tyrannical hardships' of van Dam, and they accused him of unjustly imprisoning several traders and sending them to Istanbul in chains and escorted by Ottoman soldiers. The merchants also complained that van Dam had extorted several of them to pay hefty fines. ${ }^{146}$ Van Dam retired in 1687, was still in Izmir at the time of the fire of 1688 and arrived in the United Provinces in 1689, where he died in 1709. ${ }^{147}$

Stability was finally reached with the appointment of Daniel Jean de Hochepied (1657-1723) as consul in Izmir in 1688. Daniel Jean was the son of Jan Baptista de Hochepied, a silk merchant and director in the Directorate of Levant Trade of Amsterdam. De Hochepied married Clara Colyer, daughter of former Dutch ambassador Justinus Colyer and sister of Colyer's successor Jacob. Jacob Colyer was involved as a mediator in peace talks between the Habsburg emperor and the Ottoman sultan in 1699 and 1718 in Passarowitz. Colyer and de Hochepied had a good relationship, and it seems that, some years before 1699, Jacob had been counting on the assistance of de Hochepied in his attempts at mediation. ${ }^{148}$

With the appointment of Daniel Jean de Hochepied, a family dynasty began, as the consulate of Izmir remained in the hands of the de Hochepied family until 1824, passing on from father to son..$^{149}$ The de Hochepieds consolidated their position partially through marital alliances with family members of diplomats from other European nations and also with children of important Levant traders. Daniel Jean was succeeded by his son Daniel Alexander (16891759) in 1724, who already had been interim consul three years earlier when his father made a trip to Holland. Another son, Elbert, became ambassador in Istanbul between 1746 and ${ }_{1763 .} \cdot{ }^{150}$ Daniel Alexander married Catharine, the daughter of Pietro Fremeaux. The Fremeaux family was to become one of the most distinguished families of the Dutch trading community of Izmir.

\footnotetext{
146 Ibid., pp. 315-316.

147 Schutte, Repertorium der Nederlandse vertegenwoordigers, pp. 332-334.

148 Ibid., pp. 308-309. For the relationship between Colyer and de Hochepied, see also Bianca Chen, 'Politics and letters: Gisbert Cuper as a servant of two republics', in Double agents. Cultural and political brokerage in early modern Europe, eds. Marika Keblusek and Badeloch Vera Noldus (Leiden and Boston, 2011), pp. 81-83.

149 Schutte, Repertorium der Nederlandse vertegenwoordigers, pp. 308-309 and 334-336. Family dynasties were not that uncommon. For a Venetian example, see Diego Pirillo, 'Venetian merchants as diplomatic agents: Family networks and cross-confessional diplomacy in early modern Europe', in Early modern diplomacy, theatre and soft power. The making of peace, ed. Nathalie Rivère de Carles (London and New York, 2016), pp. 183-204.

150 Schutte, Repertorium der Nederlandse vertegenwoordigers, pp. 311 and 335.
} 
When Daniel Alexander passed away in 1759, his son Daniel Jean (17271796) became the next Dutch consul, a post he occupied until 1796. Daniel Jean was not married at the time of his appointment, but he later married Marie Dunant, the widow of the English consul Samuel Crowley. ${ }^{151}$ Dunant had been born in Istanbul in 1728, and she was to bear several of Crowley's children, who were christened by the Dutch chaplain Jacob van der Vecht. ${ }^{152}$ Their son Jacques became consul between 1796 and 1810 and then from 1814 to $1824 \cdot{ }^{153}$ This means the Hochepied family presided over the Dutch trading community of Izmir for a period of almost 15 o years. ${ }^{154}$ During that time, they established marital ties with some of the most important Dutch families active in Levant trade, not only the Fremeauxs but also the van Lennep family, as Jacques de Hochepied married a daughter of David van Lennep (1712-1797), perhaps the most important Dutch merchant in eighteenth-century Izmir (see figure 6). ${ }^{155}$ Matrimonies also connected the de Hochepied family with Dutch and English diplomats. ${ }^{156}$

The stability that came with the de Hochepied family is not only demonstrated by the lack of new legislation for the Levantine consulates in the eighteenth century, which had now taken their definitive institutional form, but also by the role played by the Dutch consuls in Izmir as vice-consuls for other nations. As discussed above, it was not uncommon for nations with diplomatic representation in the Levant to extend the protection of their flag - and thus jurisdiction of their consul - over a merchant community with no diplomatic representation of its own. A consul of one nation could thus accumulate viceconsulates of other nations.

$15^{1}$ Ibid., p. 336. The marriage between Crowley and Dunant was mentioned in the handwritten notes by Crowley in a copy of the Book of Common Prayer he owned, which is now guarded in the Lambeth Palace Library in London. See http://www.levantineheritage.com/ rega.htm.

$15^{2}$ Such marriages, facilitated by religion, are an example of the social ties between the Dutch and English diplomatic elites in the Levant.

153 Schutte, Repertorium der Nederlandse vertegenwoordigers, p. 336.

154 On the de Hochepied family and their diplomatic presence in the Levant, see Marlies Hoenkamp-Mazgon, Palais de Hollande te Istanbul. Het ambassadegebouw en zijn bewoners sinds 1612 (Amsterdam, 2002), pp. 61-67.

155 For David van Lennep, see pp. $7^{-}-71$ and $157^{-158}$.

156 In 1763 , for instance, Consul de Hochepied married the widow of the former English consul, Marie Dunant, who was the daughter of a French Protestant from Istanbul, see Schutte, Repertorium der Nederlandse vertegenwoordigers, pp.335-336; and 'Crawley, Samuel (17051762)', Oxford dictionary of national biography, consulted online at http://www.oxforddnb .com/view/10.1093/ref:odnb/978o198614128.oo1.ooo1/odnb-978o198614128-e-109573. 
Daniel Jean de Hochepied, the first consul from the de Hochepied family in Izmir and who held the position between 1688 and 1723 , carried the title 'baron and magnate of Hungary' for his services to the Habsburg Empire as a diplomat after the war between the Ottoman Empire and the Holy League (1683-1699) and for the assistance he provided for the liberation of a number of Christian German slaves. ${ }^{157}$ This is perhaps why the de Hochepied family was asked to represent Habsburg interests in Izmir. Vice-consulship not only had to be requested by a nation who did not have any consulships of their own, it also had to be allowed by the Dutch authorities, more specifically the States General. In 1742, the States General allowed Consul Daniel Alexander de Hochepied to be the agent for Maria Theresia of Austria but did not let him officially become vice-consul. ${ }^{158}$

In 1758 the States General also allowed Consul Daniel Alexander de Hochepied, to accept the office of Danish vice-consul. In their considerations to allow the request, which had come from the Danish envoy in Istanbul, the States General acknowledged that the Dutch consul in Izmir had already been allowed to act as vice-consul for several European nations in the past. ${ }^{159}$ Material contained in the Dutch consular archives makes it clear that, towards the end of the eighteenth century, the Dutch consul in Izmir was also acting as vice-consul for the Holy Roman Empire, Tuscany and Sweden. He also looked after the interests of Russia and Poland. ${ }^{160}$ Some of these additional consulships were strengthened through marriage. Gerhard Heidenstam, Swedish envoy in Istanbul, married Catharine de Hochepied, a daughter of the Dutch consul in Izmir, Daniel Jean de Hochepied. Daniel Jean was Dutch consul from

157 Schutte, Repertorium der Nederlandse vertegenwoordigers, p. 334; see also Heeringa and Nanninga, Bronnen tot de geschiedenis, 2: pp. 146-147.

158 Isaac Scheltus, Groot placaatboek, vervattende de placaaten, ordonnantien en edicten van de hoog mog. heeren Staten Generaal der Vereenigde Nederlanden; en van de edele groot mog. heeren Staaten van Holland en Westvriesland mitsgaders van de edele mog. heeren Staaten van Zeeland (The Hague, 1770), 7: p. 536, 'Resolutie van de Staaten Generaal, waar by aan den Consul Hochepied te Smirna word gelaaten, om den titel van graaf van Hungaryen aan te neemen, of niet, en dat hy de zaaken van de koningin van Hungaryen zal mogen bevorderen, zonder het caracter van consul of diergelyke aan te neemen', 10/ 05/1742.

159 Didericus Lulius and Joannes van der Linden, Groot placaatboek, vervattende de placaaten, ordonnantien en edicten van de hoog mog. heeren Staten Generaal der Vereenigde Nederlanden; en van de edele groot mog. heeren Staaten van Holland en Westvriesland mitsgaders van de edele mog. heeren Staaten van Zeeland (Amsterdam, 1795), 8: pp. 237-238, 'Resolutie van de Staaten Generaal, waar by aan den Consul de Hochepied te Smirna word toe gestaan de Deensche consulaire affaires aldaar waar te nemen', 13/11/1758.

Slot, Inventaris van het archief, pp. 64-72. 
1759 until his death in 1796, while also being vice-consul for the Holy Roman Empire and Sweden. ${ }^{161}$

From an institutional point of view, it is important to note that, in cases where the Dutch consul acted as vice-consul for another nation, he did so independently from his office as Dutch consul. As Danish vice-consul, for instance, he could count on Danish personnel, such as a Danish chancellor, which ensured that administration belonging to the Danish vice-consulate remained completely separate from that belonging to the Dutch consulate.

\subsection{The Consular Protection of Jews}

The Dutch consul in Izmir not only exercised authority as consul over the Dutch traders in the city, and as vice-consul over a variety of other merchants, he also took a number of other groups under his protection. As will be seen, Dutch Levant trade relied to a great extent on Ottoman middlemen. By the mideighteenth century, this group had come to include Armenians and Greeks, but a century earlier, these were without exception Portuguese Jews who had migrated to the Ottoman Empire. ${ }^{162}$ The Ottoman Empire's non-Muslim communities that were monotheistic fell under the taife system, allowing them protection and the ability to live as zimmis in the Ottoman Empire. ${ }^{163}$ Different communities of zimmis were called millets or taifes. There is a slight difference between the two terms; the first meant 'religion' or 'religious community', while the second meant 'group' and was broader - it could also include professional groups. ${ }^{164}$ According to Merlijn Olnon, taife resembled the European

161 After the end of Heidenstam's tenure, the couple moved to Izmir. Curiously, Heidenstam and his wife were involved in the first recorded opera performance in Istanbul - in 1786 at the Swedish Palace. Heidenstam had set the piece to music and acted as conductor of the orchestra, while his wife acted in it, next to the daughter of the Spanish ambassador, as well as Swedish, Venetian, Habsburg and Spanish embassy officials. Suna Suner, 'The earliest opera performances in the Ottoman world and the role of diplomacy', in The age of Mozart and Selim III (1765-1808), vol. 1 of Ottoman Empire and European theatre (Wien, 2013), eds. Michael Hüttler and Hans Ernst Weidinger, pp. 187-191; see also Sture Theolin, The Swedish palace in Istanbul: A thousand years of cooperation between Turkey and Sweden (Istanbul, 20oo), p. 194. The marriage between Gerhard Heidenstam and Catharine de Hochepied was announced in the Hollandsche Historische courant, o2/ o8/1783.

162 Olnon, 'Brought under the law of the land', p. 147. For the early history of Jews in the Ottoman Empire, see Joseph R. Hacker, 'The rise of Ottoman Jewry', in The early modern world, 1500-1815, vol. 7 of The Cambridge history of Judaism, eds. Jonathan Karp and Adam Sutcliffe (Cambridge, 2018), pp. 77-112.

163 Sonyel, 'The protégé system'.

164 The difference and different use over time, as well as in European and Ottoman documents, is further explained in Olnon, 'Brought under the law of the land', pp. 38-41. 
early modern use of nation. ${ }^{165}$ The Greek Orthodox, Armenian and Jewish communities were all taifes, which meant they enjoyed a certain degree of political and legal autonomy. This included the possibility of intracommunity adjudication. The European trading communities easily fell into this system after obtaining capitulations.

Merchants and brokers belonging to one of the taifes who were involved in commercial transactions with Europeans stood in a unique position that subjected them to vulnerabilities but also provided them with certain strengths. A good example of the pressure Izmir's Jews were able to exercise can be found in the problems faced by Dutch Consul van Dam in 1677, when a number of Jewish merchants standing under Dutch protection claimed the repayment of loans that had been given to Dutch merchants. The Jewish creditors threatened them with litigation before an Ottoman qadi court and petitioned the English to support their cause. They obtained the support of the grand duke of Tuscany through the Jewish community of the free port of Livorno, as well as that of one of the wealthiest Jewish traders in Amsterdam at the time, Jacob de Pinto. The situation led to a Jewish embargo and a standstill of Dutch trade in Izmir and angry letters from the States General to Consul van Dam. It was resolved by Dutch acceptance of repayment in the following years. ${ }^{166}$

The event might still have resonated in 169 , when the grand duke of Tuscany asked the Dutch consul to take several of his subjects, Portuguese Jews, under his protection. Van Dam had gone, succeeded as consul by Daniel Jean de Hochepied, who thought it was a good idea, writing to the States General that he would accept it unless they objected. It seemed a good way of expanding Dutch influence. Dutch traders in Izmir, however, had already objected to the idea, perhaps remembering the events that occurred two decades earlier. They feared the extension of Dutch protection to Tuscan Jews would cause a loss of commissions from Jewish traders, as well as from merchants established in Italy, but this was much to the consul's surprise, because several other European states, particularly France, were hoping for the opportunity to protect the same Tuscan subjects. ${ }^{167}$ In his letters to the United Provinces, the consul explicitly stated that, if he refused protection to the Tuscan Jews, they would undoubtedly be 'received with open arms by the other consuls, particularly the

165 Ibid., p. 41.

166 Ibid., pp. 147-152.

167 Heeringa and Nanninga, Bronnen tot de geschiedenis, 2: pp. 254-255, Consul Daniel Jean de Hochepied to the States General, Izmir, 19/11/169o, and pp. 256-257, Consul Daniel Jean de Hochepied to the States General, Izmir, 04/07/1691. 
French, who protect all persons without distinction'.168 It would harm Dutch commercial interests, which he felt was a pity, especially considering it was a 'right and privilege permitted by the imperial capitulations'. ${ }^{169}$ The Directorate of Levant Trade, whose advice was sought in the matter, agreed with the consul and felt it might benefit Dutch commercial interest, but they suggested the protection should only be given on the condition that the Tuscan Jews would agree to take the same oath as the Dutch nationals. ${ }^{170}$

The Dutch national oath was an instrument that was introduced in the Levant by the States General in their regulation from 6 June 1615. It was an oath destined to prevent fraud on the part of Dutch merchants, skippers and commercial agents active in Levant trade and shipping. The new regulation forced them to give Dutch consuls and vice-consuls, as well as the representative in Istanbul, access to their commercial documents and to give lists of everything - money and merchandise - that they received from the United Provinces or shipped to the Levant so that Dutch officials could determine the correct taxes to be paid on them, which included the consular taxes used to fund consulates. By taking the national oath, merchants, agents and skippers swore that their documents were sincere, honest and truthful. ${ }^{171}$ The national oath, and who would be obliged to take it, was met with protest by Dutch merchants, who often argued that Ottoman traders involved in Dutch Levant trade had an unfair advantage because they were not obliged to take the oath. The practice remained controversial until the 168os, a decade after new legislation had attempted to cement the obligation to take the national oath by making refusal a punishable offence. Further legislation in 1688 finally settled the matter. ${ }^{172}$

It seems that initially, the condition of the oath in the case of the Tuscan Jews was met, and Dutch protection was extended to the Tuscan Jews in Izmir but was challenged a few years later. In 1694, it was rumoured that the new grand vizier, Sürmeli Ali Pasha, wanted to expel the Portuguese Jews from

168 Heeringa and Nanninga, Bronnen tot de geschiedenis, 2: pp. 256-257, Consul Daniel Jean de Hochepied to the States General, Izmir, 04/07/1691, on p. 257, '[...] door de andere heeren consuls met open armen werden ontfangen, principaal door de Francen, die alle personen sonder onderscheyd beschermen $[\ldots]$ '.

169 Ibid., '[...] een regt en privilegie is bij de kijserlijke capitulatie vergund [...]'.

170 Heeringa and Nanninga, Bronnen tot de geschiedenis, 2: p. 257, Directorate of Levant Trade to the States General, Amsterdam, 14/og/1691.

171 Cau, Groot placaet-boeck, 2: pp. 1333-1336, 'Acte, waer by gheconsenteert wort ten behoeve vanden orateur tot Constantinopolen', o6/06/1615.

172 For the controversies surrounding the oath in the 1670 s and 168 os, as well as the new legislation, see pp. 81-82 and 99-103. 
Ottoman lands and perhaps even go so far as to confiscate their goods. ${ }^{173}$ The Dutch ambassador in Istanbul, Jacob Colyer, warned the consul in Izmir, who informed the Jews under his protection. ${ }^{174}$ According to the first letter the consul sent to the States General about this, the vizier had been instigated by the French ambassador. When informed of these plans, the Portuguese Jews under Dutch protection planned to send a delegation to Istanbul to discuss matters with the Dutch ambassador. The consul expressed his contentment about this, hoping the Jews would be able to arrange a solution so 'we can maintain, to the regret of our enemies, this point of the capitulations with regard to the protection of foreigners.' ${ }^{175}$ Sürmeli's plans might have been motivated by the fact that he was heavily in debt, but the Dutch ambassador, supported by the Rais Effendi, managed to turn his mind, promising him financial compensation. ${ }^{176}$ The Dutch ambassador and consul agreed that this compensation needed to be paid by the Portuguese Jews in Izmir, but they refused. For de Hochepied, it showed the ingratitude and little confidence those people have with regards to us, desiring to enjoy all privileges from our capitulations, without it costing them a penny'.177 The consul concluded that, should the Jewish refusal continue, he would withdraw Dutch protection. ${ }^{178}$

While it cannot be explicitly proven that anti-Semitic motivations were behind the consul's remarks, it should be acknowledged that a certain animosity existed in regard to them as a community considered as different. Olnon acknowledges as much by stating that 'national sovereignty was clearly catching up with ethno-religious group identities as a determinant of legal status'.179

173 Heeringa and Nanninga, Bronnen tot de geschiedenis, 2: pp. 262-263, Consul Daniel Jean de Hochepied to the States General, Izmir, 24/06/1694. For Sürmeli Ali Pasha's tenure, see Michael Nizri, Ottoman high politics and the Ulema household (Basingstoke, 2014), pp. $105^{-107}$.

174 Jacob Colyer had succeeded his father Justinus as ambassador in 1688. Schutte, Repertorium der Nederlandse vertegenwoordigers, pp. 308-309. His brother-in-law Daniel Jean de Hochepied, who was to become Dutch consul in Izmir, initially was his secretary.

175 Heeringa and Nanninga, Bronnen tot de geschiedenis, 2: pp. 262-263, Consul Daniel Jean de Hochepied to the States General, Izmir, 24/o6/1694, on p. 263, '[...] dit point van onse capitulatie, in spijt onser vijanden, in 't reguarde van het protigieeren der vreemdelingen sullen konnen maintineeren [...]'

176 Heeringa and Nanninga, Bronnen tot de geschiedenis 2: pp. 263-264, Consul Daniel Jean de Hochepied to the States General, Izmir, 16/07/1694. This further confirms the thesis that the vizier was looking for a way to solve his financial troubles.

177 Ibid., on p. 264, '[...] de ondanckbaarheyd en het wijnig vertrouwen, soo dat volk op ons heeft, die wel te desideeren van alle onse voorregten en previligiën onser kapitulatie te jouïsseeren, sonder dat het haar een stuyver soude kosten'.

178 Ibid.

179 Olnon, 'Brought under the law of the land', p. 153. 
The Dutch took action, and they petitioned for a ferman that revoked Jewish exemption from the poll tax if they were active as middlemen for the Dutch. Although they succeeded in getting it, it does not seem to have been used. ${ }^{180}$ It did alienate the Jewish traders in question from the Dutch, and in September 1695, the Dutch ambassador wrote that the Jews had renounced Dutch protection and accepted that of France, claiming they were allowed to do so as free people who were acting in line with the relevant articles in the French capitulations. They had also obtained a sentence from the qadi in which he stated he would not interfere, as it was a matter of a dispute on protection between two foreign nations, which, the qadi stated, could not be adjudicated by the sultan. ${ }^{181}$ By the time Colyer had sent this letter, Grand Vizier Sürmeli Ali Pasha had already been dismissed and executed for his inability to pay his debts. ${ }^{182}$

The problems with the Tuscan Jews did not stop Dutch efforts to extend their protection to Jews - who made several complaints that the Dutch consul in Izmir was charging them fees that were too high. ${ }^{183}$ Several Jewish traders still figure amongst the lists of members of the Dutch community in Izmir for 1759 and 1766 (see tables 1 \& 2), but nationality was not clearly delineated throughout the early modern period, and it is not clear whether they were foreigners under Dutch protection, as had been the case for the Tuscan Jews eighty years earlier, or whether they had ties to the United Provinces that qualified them as Dutch subjects in the Levant. ${ }^{184}$ In $175^{8}$, a Jewish merchant who was established in Izmir, Daniel Chaves, petitioned the States General in an attempt to obtain the same rights as the Dutch merchants in Izmir. He explained that the Chaves firm had been established in Amsterdam 'for more than a hundred years' before his grandfather, a Dutch Jew, had relocated the

\footnotetext{
180 Ibid.

181 Heeringa and Nanninga, Bronnen tot de geschiedenis, 2: pp. 264-266, Ambassador Jacob Colyer to the States General, Istanbul, o7/o9/1695. In his letter, Colyer mentioned the same Jews were the cause of an earlier dispute between the Dutch and the English in Izmir. This might be a reference to the events of 1668, as at the time, the Jewish creditors had complained to the English consulate about Dutch Consul van Dam.

182 This happened in May 1695. Nizri, Ottoman high politics, pp. 105-107.

183 Heeringa and Nanninga, Bronnen tot de geschiedenis, 2: p. 264. Of course, the possible protection of Jewish traders in this sense was only possible for non-Ottoman Jews and should not be confused with the protection bought by the 'honorary dragomans'.

184 Jews could become burghers of Dutch cities, but it did not pass on to their children, which necessitated the formal extension of Dutch protection, even if it was a Dutch Jew who went to the Levant. Dutch Jews only obtained full citizenship rights in 1796. Hans Daalder, 'Dutch Jews in a segmented society', in Paths of emancipation.Jews, states, and citizenship, eds. Pierre Birnbaum and Ira Katznelson (Princeton, 1995), pp. 37-59.
} 
firm to Izmir. ${ }^{185}$ There, he as well as his children had always enjoyed consular protection. Although he was born in Izmir, Daniel Chaves assumed he would enjoy the same protection 'ex natura', but he encountered a number of difficulties that made him think this was not the case. ${ }^{186}$ The States General decided to grant Chaves' request and sent a letter to the consul and ambassador to protect Chaves and 'make him enjoy all freedoms, rights and privileges the free and ordinary merchants of these lands are enjoying there.. 187

It seems, however, that in practice, this was not sufficient as, twenty-one months later, Daniel Chaves appeared on a list of members of the Dutch trading community in Izmir. He was described as born in Izmir but of Dutch extraction and married, with a house in the city as well as an outside residence in Bornova, eight kilometres northeast of Izmir (the place is mentioned as 'Burnabad' on figure 4). ${ }^{188} \mathrm{He}$ had done well apparently, but he also had purchased an official berat confirming he was an Ottoman under Dutch protection. His earlier petition had been made in the hopes of obtaining such protection free of charge but apparently that had not worked out. In comparison, a number of Jewish traders who had been born in the United Provinces managed to get such protection for free. ${ }^{189}$ Chaves remained a respected member of the Dutch community, and when his firm went bankrupt in 1766, Consul Daniel Jean de Hochepied testified that Chaves was a 'good and honest man'.190 The petition by Daniel Chaves is a good example of how merchants tried to best use a situation in which nationality was not immediately clear. The sometimes-blurry status of Dutchmen or persons born in the Ottoman Empire to Dutch parents was also a worry for officials, and the States General issued several laws confirming the Dutch nationality of their Ottoman-born consuls in Izmir and ambassadors in Istanbul. Elbert de Hochepied, for instance, was born in Izmir in 1706; son of the Dutch consul there, Daniel Jean de Hochepied, and Clara Colyer, daughter of the former Dutch ambassador in Istanbul. Elbert

185 NA, $\mathrm{N}^{\circ}{ }_{1.02 .22}$ 'Archief van het Nederlandse Consulaat te Smyrna, (1611) 1685-1811 (1837)' (hereafter NACS), $\mathrm{N}^{\circ} 30$ ('Brieven en extract-resoluties Staten-Generaal'), 'Request Daniel Chaves', $18 / 01 / 1758$, ' [...] meer dan honderd jaar [...]'.

186 Ibid. The request never specified what kind of difficulties.

187 Ibid., '[...] mitsgaders te doen goudeeren van alle zoodanige vrijheeden rechten en privilegien als vrije en ordinaris cooplieden deser landen aldaar zijn genietende'.

188 See table 2. A 1766 list refers to Chaves as the child of a mother and father from Holland. NACs, $\mathrm{N}^{\circ} 14$ ('Uitgaande brieven, 1766-1774'), Daniel Jean de Hochepied to Ambassador Willem Dedel, Izmir, o8/12/1766.

189 See table 1.

190 Heeringa and Nanninga, Bronnen tot de geschiedenis, 4: p. 43, Consul Daniel Jean de Hochepied to Fagel, Izmir, 16/o4/1766, '[...] een braaf ende eerlijk man [...]'. 
went to study law in Leiden in 1722 and was made secretary of the Orphan Chamber (Weeskamer) in Haarlem in 1735 before he became Dutch ambassador in Istanbul in $1746 .{ }^{191}$ After he became secretary in Haarlem, he wanted to get his status as Hollander confirmed and petitioned the States General, which issued a resolution instructing that de Hochepied would be held as a born Hollander. ${ }^{192}$

\subsection{Purchasing Protection: The Beratlis or Honorary Dragomans}

Men such as Chaves, an Ottoman with family ties going back to Amsterdam, could attempt to obtain Dutch protection on the basis of the status of their forefathers. This was a particularly complicated claim in Chaves' case because he was Jewish, and it seems it did not work out. There was, however, another option available to men in his position, and family ties to the United Provinces did not play a formal role in this option. Over time, it had become possible for non-Muslim Ottomans, such as Greeks, Jews or Armenians, who often acted as middlemen in European-Ottoman trade, to purchase European legal status through a berat. This practice was called the protégé system, and its beneficiaries were protégés, beratlıs or barattaires. The protégé system had grown out of the right for European nations to employ a number of Ottoman nonMuslims dragomans, who served as interpreters and legal brokers between themselves and Ottoman justice. It was the prerogative of ambassadors and consuls to appoint them, a privilege given by the sultan in the capitulations. These dragomans became attached to diplomatic European institutions and, as such, enjoyed a certain level of protection and insertion into European legal systems, including the right to be adjudicated by the consular court of the protecting nation. ${ }^{193}$

During the eighteenth century, the dragoman system was commercialised, and dragoman status was sold by European ambassadors, thereby gaining additional income. Although the Ottoman Empire always remained conscious of the number of protégés attached to the different European embassies and consulates, the system expanded, even leading to 'dragoman dynasties', where the post effectively became hereditary. ${ }^{194}$ This followed an earlier practice in

191 Schutte, Repertorium der Nederlandse vertegenwoordigers, p. 311.

192 Scheltus, Groot placaatboek, 6: p. 73, 'Resolutie, Mr. Elbert de Hochepied, tot Smirna gebooren, te houden voor een Hollander', 11/o7/1736. His brother Jacob had done the same in 1721. Ibid., p. 471, 'Resolutie, Jacob de Hochepied, in Turkyen gebooren, te houden voor een Hollander', 26/11/1721.

193 See footnote 47 on p. 29.

194 Van den Boogert, The capitulations, pp. 63-116. For the commercialization of the system and the price attached to obtaining dragoman status, see Artunç, 'The price of legal 
which the position of dragoman as interpreter passed from father to son. In the seventeenth century, for instance, Venetian diplomats looked to replace dragomans with their sons, and a number of families employed different sons as dragomans for different European nations. ${ }^{195}$ As official dragomans continued to be employed by diplomatic institutions, Europeans distinguished buyers of the status by labelling them honorary dragomans, protégés or beratlıs. ${ }^{196}$ While this status gave them some of the same privileges that foreigners enjoyed in the Ottoman Empire, they remained subjects of the sultan. Beneficial as it could be, obtaining dragoman status was expensive. A Dutch berat cost 2,500 kurus in 1759, almost eighteen times the yearly income of an unskilled worker in Istanbul and almost nine times that of a skilled worker. By 1803, the price had risen to 4,500 kurus, or about thirty-two times the yearly income of an unskilled worker and sixteen times that of a skilled one. ${ }^{197}$ At its zenith in 1757 , the Dutch had thirty beratıs, ten of them in Izmir. Both the French and English sold more berats (forty-six and forty-three respectively) but less of them (four and five respectively) resided in Izmir. ${ }^{198}$

The purchase of a berat provided legal protection and fiscal exemptions for as long as the beratı held his nominal position, and this included his sons as well as two 'servants'199 for life. From the second half of the eighteenth century onwards, the berats of the servants or hizmetkârs were sold separately, at a lower price than the main berats but offering the same privileges. ${ }^{200}$ The two

institutions', pp. 20-48. An older version of the article is available as, 'The protégé system and berath merchants in the Ottoman Empire: The price of legal institutions', working paper, Yale University (2013), consulted online at http://www.econ.yale.edu/ egcenter/ berats_third_draft.pdf. For these 'dragoman dynasties' in the late eighteenth and early nineteenth centuries, see de Groot, 'Dragomans' careers'; and 'The dragomans of the embassies in Istanbul 1785-1834', in Eastward bound. Dutch ventures and adventures in the Middle East, eds. Geert Jan van Gelder and Ed de Moor (Amsterdam and Atlanta, 1994), pp. ${ }^{130}-15^{8}$.

195 Rothman, 'Interpreting dragomans', pp. $777-778$ and 781.

196 Van den Boogert, The capitulations, pp. $76-77$.

197 Artunç, 'The protégé system', p. 10.

198 Artunç, 'The price of legal institutions', p. 728.

199 Women (and thus daughters in this case) are often not mentioned in this context because they were not taxable, but the wives of beratlıs, for instance, did benefit from the legal protection of the husbands. See for instance the handling of the estate of Greek dragoman for the Dutch consulate, Dimitri Dallāl, discussed in van den Boogert, The capitulations, pp. 179-205.

200 Ibid., p. 7o. Because servant status had to be confirmed by an official ferman, European sources often refer to these men as firmanlis (fermanlis). Ottoman sources use the term hizmetkâr (servant). Van den Boogert, The capitulations, p. 68. Over time, these servant berats were sold to such an extent that they no longer automatically belonged to actual servants. 
main advantages of buying a berat were exemption from certain taxes, including the haraç, and the lowering of others, such as Ottoman custom duties and access to the European legal system for settling disputes, which included the right to be judged as a defendant by the consular court of the European nation selling the protection. It meant that 'a beratlı was practically a European subject armed with extraterritorial rights. ${ }^{201}$ However, a number of differences remained. In the Dutch case, the Ottoman beratlıs were considered part of the Dutch trading community, but they did not have to take the national oath. They also paid higher consular duties than Dutch nationals. ${ }^{202}$ The position of these protégés was often contested by Ottoman officials and Dutch diplomats and traders. There were times when the Ottomans attempted to curtail the practice of selling berats in an attempt to exercise more control over their subjects, who had come under European protection for commercial or legal purposes. ${ }^{203}$

In the second half of 1766 the Dutch community increasingly came under Ottoman scrutiny concerning the Ottoman protégés attached to it (see table 1), and Consul de Hochepied wrote to the Dutch ambassador in Istanbul that he would never recommend anyone for a berat unless they were people of 'honour and reputation.' ${ }^{204}$ In December, a hatt-ı şerif (sultanic writ) was issued in Izmir, warning consuls to no longer accept Ottomans under their protection and demanding all Ottoman subjects who had not purchased a berat to dress 'following the order of the Great Lord, wearing black vests.' ${ }^{205}$ De Hochepied wrote that a similar hatt-ışerif had been issued ten years earlier and that he had not accepted new protégés since then, sending his dragomans and the chancellor to the qadi with a list of members of the Dutch trading community as evidence. In return, he demanded from the qadi that no one was to lay a hand on his subjects who figured on the list nor to demand the haraç. He even declared he was willing to pay the haraç himself if the Ottomans insisted. ${ }^{206}$ Apparently,

\footnotetext{
201 Artunç, 'The price of legal institutions', p. 725.

202 Contemporary sources confirm this status. See for instance a letter sent by the Dutch treasurer in Izmir to the Directorate of Levant Trade, in which he summed up these benefits. Heeringa and Nanninga, Bronnen tot de geschiedenis, 4: p. 186, Treasurer C.G.N. Schutz to the Directorate of Levant Trade, Izmir, o3/o6/1774.

203 Van den Boogert, The capitulations, pp. 105-112.

204 NACS, $\mathrm{N}^{\circ}{ }_{14}$, Consul Daniel Jean de Hochepied to Ambassador Willem Dedel, Izmir, 16/10/ 1766.

205 Ibid.

206 Which demonstrates that there still remained a small contingent of Jewish traders with family ties to the United Provinces who stood under Dutch protection without purchasing it.
} 
they did not, and de Hochepied only mentioned that two Livornese Jews had been released after they had been arrested by mistake. ${ }^{207}$

A few days later, Consul de Hochepied wrote to the Dutch ambassador in Istanbul that rumours were spreading in Izmir about the desire of certain Ottoman officials to turn all European-born Jews into Ottoman subjects, which would fit within a larger effort to reduce the number of Ottoman beratlıs. ${ }^{208}$ The consul had obtained a list of names that the Ottomans were using for this purpose, which contained seven Jews and nine Ottomans who had been working for the Dutch.

De Hochepied wanted the ambassador to arrange a ferman allowing protection for the three Ottoman men who never had one, as well as for one of the Jews, Moise Pereira. He was an old man, born in the United Provinces, who had served the consulate for thirty-five years and whose life would be made easier with a berat. ${ }^{209}$ In the end, it seems the Ottoman threats remained idle, but they did serve as a reminder to the Europeans that no privilege was permanently given and that they remained guests at the pleasure of the Porte.

\subsection{A Community of Competing Traders}

Izmir was conveniently located on the western coast of Anatolia near the Aegean Sea (see figures $3 \& 4$ ). It had been an important port city since Antiquity and was well suited for both overseas and overland trade because of its geographical position. It relied on its hinterland in Anatolia for the production of cotton and continued to play an important commercial role during the Middle Ages. It further expanded its commercial and industrial activities after the Ottoman conquest of 1426 . By the end of the fifteenth century, the city had a flourishing trade in luxury items, such as cloth and decorated vases. ${ }^{210}$ European traders had been active there since the Middle Ages and privileges were given to Venetians and merchants from Cyprus in 1207, to the Genoese in 1304, to members of the Holy League in 1348 and more extensive ones to Venetian and Genoese traders after 1350. ${ }^{211}$ During this period, Izmir was still a

207 NACs, $\mathrm{N}^{\circ}{ }_{14}$, Consul Daniel Jean de Hochepied to Ambassador Willem Dedel, Izmir, 04/12/ 1766.

208 NACS, $\mathrm{N}^{\circ}{ }_{14}$, Consul Daniel Jean de Hochepied to Ambassador Willem Dedel, Izmir, o8/12/ 1766.

209 Ibid.

210 Frangakis-Syrett, The commerce of Smyrna, p. 23.

211 Olnon, 'Brought under the law of the land', p. 143. 
TABLE 1 Ottomans working for the Dutch consulate in 1766

\begin{tabular}{|c|c|c|}
\hline Name & Additional information & Status \\
\hline Jacob Pisa & born in Amsterdam, not married & Jewish \\
\hline Moise Pereira & born in Amsterdam, married in Izmir & Jewish \\
\hline Judah Pereira & son of Moise Pereira & Jewish \\
\hline Isaac Pereira & son of Moise Pereira & Jewish \\
\hline Joseph Pereira & son of Moise Pereira & Jewish \\
\hline Isaac Nunes & born in Amsterdam, not married & Jewish \\
\hline $\begin{array}{l}\text { Daniel Chaves (and } \\
\text { son) }\end{array}$ & born and married in Izmir & $\begin{array}{l}\text { Jewish holding } \\
\text { a ferman }\end{array}$ \\
\hline Diodato Abro & $\begin{array}{l}\text { employed by the Directorate of } \\
\text { Levant Trade }\end{array}$ & beratlı \\
\hline Copruli Ammin & $\begin{array}{l}\text { employed by the Directorate of } \\
\text { Levant Trade }\end{array}$ & beratlı \\
\hline $\begin{array}{l}\text { Pitako Hagi } \\
\text { Antonoğlu }\end{array}$ & & beratlı \\
\hline Tschellik Torcce & & beratlı \\
\hline Isaie di Massé & & beratlı \\
\hline Abram Assecri & & beratlı \\
\hline Januachi Malcozzi & $\begin{array}{l}\text { tax collector for the Directorate of } \\
\text { Levant Trade }\end{array}$ & $\begin{array}{l}\text { neither berat } \\
\text { nor ferman }\end{array}$ \\
\hline Gualtieri Gallo & $\begin{array}{l}\text { conducted visitation of ships for the } \\
\text { Directorate of Levant Trade }\end{array}$ & $\begin{array}{l}\text { neither berat } \\
\text { nor ferman }\end{array}$ \\
\hline Jorgachi Amira & $\begin{array}{l}\text { employed at the consulate's chancery } \\
\text { and treasury }\end{array}$ & $\begin{array}{l}\text { neither berat } \\
\text { nor ferman }\end{array}$ \\
\hline
\end{tabular}

SOURCE: NACS, $\mathrm{N}^{\circ} 14$, CONSUL DANIEL JEAN DE HOCHEPIED TO AMBASSADOR WILLEM DEDEL, IZMIR, 08/12/1766

fairly modest town that would only transform into a trade hub of international proportions with the arrival of French, English and Dutch traders during the first half of the seventeenth century. ${ }^{212}$

212 For general analyses of European trade in Izmir that are indispensable, see Goffman, 'Izmir'; and Frangakis-Syrett, The commerce of Smyrna. For the establishment of Dutch trading relations with Izmir, see Fikret Yllmaz, 400 years in Izmir: Izmirian Dutch people and trade relations between Izmir and Holland (Izmir, 2012). 


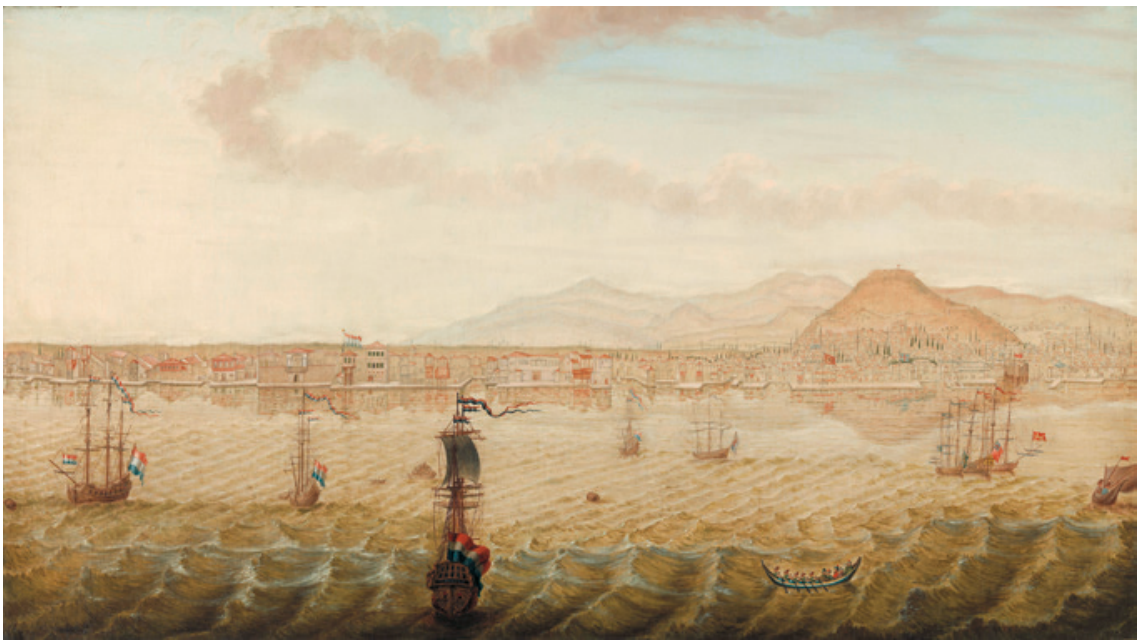

FIGURE 3 View of Smyrna (Izmir) by N. Knop, 1779

FROM THE COLLECTION OF THE RIJKSMUSEUM, AMSTERDAM

It was this 'northern invasion' that made Izmir the most important centre for Ottoman trade with Europe. For some observers, it changed the city a great deal. The Ottoman traveller Evliya Çelebi (1611-1682) visited Izmir in 1671 and remarked that 'every year a thousand ships come and go to have their goods sold in this city of Izmir. Thus, this place has become a truly shining trading port adorned with bustling quays. And because of these malevolent Frankish ships arriving, half the city of Izmir resembles the land of the Franks.'213 The observation that half the city looked European was an exaggeration; the European quarters were confined to an area in the lower part of the city near the seashore, around 'Street of the Franks' (see figure 4). ${ }^{214}$ The area was surrounded by the Armenian and Jewish quarters, while the Greeks, often from Anatolia or the island of Chios, gradually incorporated themselves into the higher located Ottoman Muslim parts of the city. ${ }^{215}$ The French artillery officer Claude Alexandre, Comte de Bonneval, wrote upon his arrival in Izmir in 1740 that 'the prettiest and most agreeable area of the city is the street that is called [street] of the Franks, because all the European merchants reside there. This street is filled with very pretty houses, all with very large galleries that extend

\footnotetext{
213 As quoted from and translated by Olnon, 'Brought under the law of the land', p. 141.

214 For an analysis of the geography of the city in the sixteenth and seventeenth centuries, see ibid., pp. 82-140.

215 Ibid., pp. 98-99.
} 


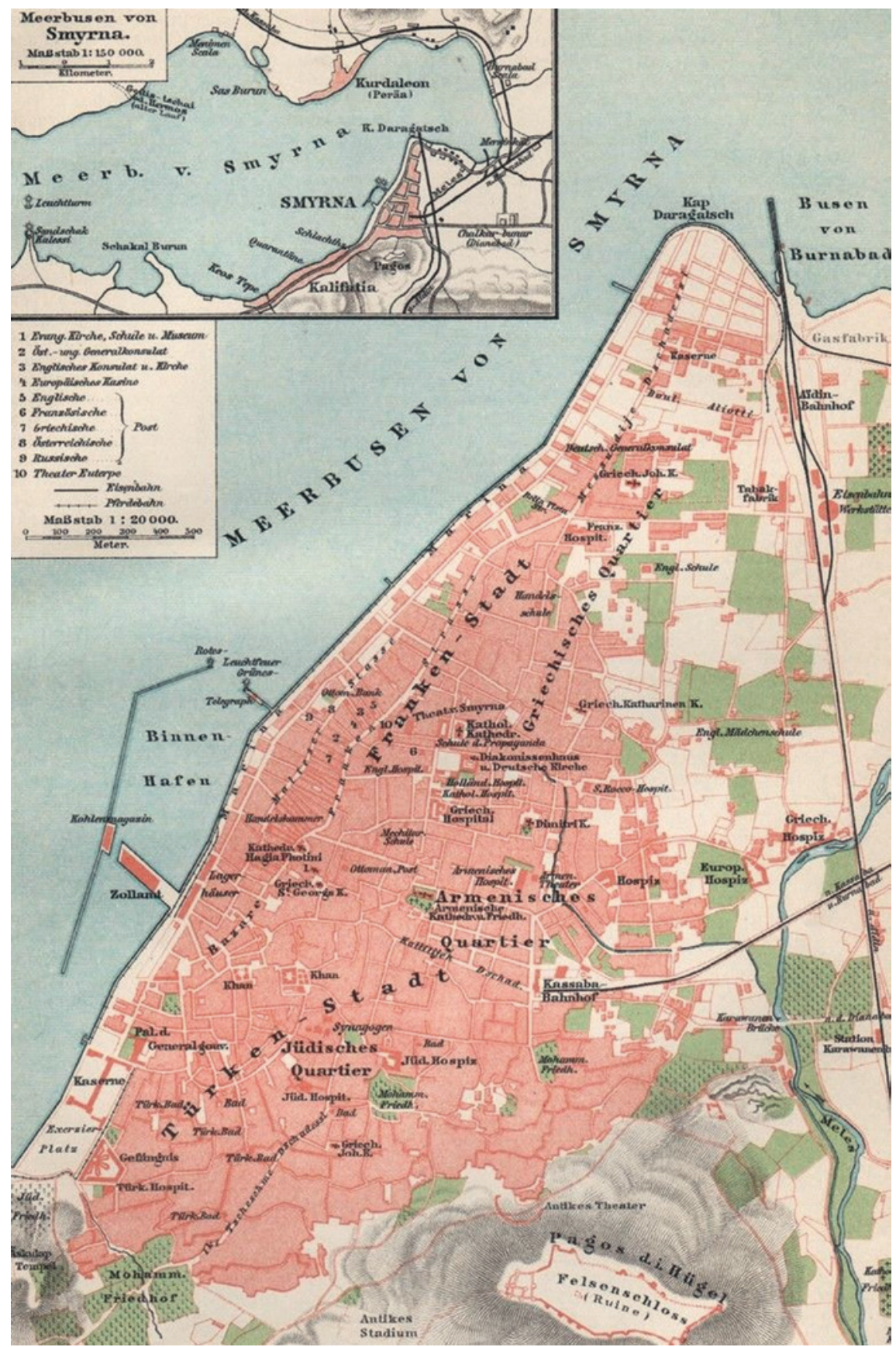

FIGURE 4 German map of Smyrna (Izmir). Lithograph, $25 \mathrm{~cm} \mathrm{x} 16 \mathrm{~cm}$. FROM THE BROCKHAUS LEXIKON, 1895 
all the way to the sea and particularly on the docks, which is strictly separated from where the galleries of the Great Lord are.'216 When the Frenchman made his observation, the European population of Izmir was limited to a number between 700 and 800 , of which 250 to 300 were French, of a total population that amounted to 100,000. ${ }^{217}$ By that time, the three largest European trading nations in Izmir were, in order of importance, France, England and the United Provinces.

The Dutch mercantile community in Izmir was never very large. It is not easy to make estimates of the total European presence in the seventeenth and eighteenth centuries for lack of numbers, but Merlijn Olnon has collected data on the basis of several sources from the late seventeenth century. One of the most accurate reports on the European population seems to be that of Antoine Galland, who visited Izmir in 1672 and 1678 and counted twenty-three Dutch merchants, with three of them married to local women, and an additional eight clerks. Additionally, he mentioned that one Florentine merchant, one Florentine clerk and one trader from Siena all stood under Dutch protection. In comparison, the French community consisted of thirty merchants, and the English counted seventy. ${ }^{218} \mathrm{~A}$ list of all members of the Dutch community compiled by Consul Daniel Jean de Hochepied in October 1759 included thirteen Dutch merchants, sixteen scribes, five artisans, three servants, a treasurer, chaplain, chancellor and physician. ${ }^{219}$ The list also included two Genoese merchants, and one of them was married to a Dutch woman, who stood under

216 'Le plus bel endroit et le plus agréable de la ville est la rue qu'on appelle des Francs, parce que c'est où résident tous les négociants européens. Cette rue est remplie de très belles maisons toutes accompagnées de très grandes galeries qui avancent dans la mer, et particulièrement sur la darse, qui est fort séparé où l'on tient les galères du Grand Seigneur', quoted from NA, $\mathrm{N}^{\circ}{ }_{1.10 .41}$ (Archief van de familie de Hochepied), $\mathrm{N}^{\circ} 101$ ('Lezing, gehouden door Dr. Varenne voor de Alliance Française te Smyrna over Bonneval Pasja', S.d.). Later in his life, de Bonneval converted to Islam and worked for the Ottoman sultan. See Julia Landweber, 'Fashioning nationality and identity in the eighteenth century: The Comte de Bonneval in the Ottoman Empire', The international history review, 30:1 (2008): pp. 1-31.

217 Marie-Carmen Smyrnelis, 'Les européens de Smyrne du XVIIe au XIXe siècle: Citadins ou non?' in L'urbain dans le monde musulman de Méditerranée, ed. Jean-Luc Arnaud (Tunis, 2005), pp. 121-133.

218 Olnon, 'Brought under the law of the land', pp. 253-255. The French community was larger in total due to a large presence of people who were not merchants, such as artisans, doctors, pharmacists, surgeons and other personnel.

219 Heeringa and Nanninga, Bronnen tot de geschiedenis, 3:pp. 395-397, 'Lijst van Nederlanders en Nederlandse geprotegeerden te Smirna', 10/10/1759; see table 2. Daniel Chaves' profession was not mentioned, but we know from other sources that he was a merchant (see pp. 59-6o). 
Dutch protection. The total number of male members of the Dutch community of Izmir in 1759 amounted to forty-five persons, the forty-four that figured on the list and the consul. In 1766, the Ottoman authorities compiled a list of all the male members of the Dutch trading community of Izmir, reaching a number of forty-eight. ${ }^{220}$

Although the ages of the men appearing in both the 1759 and 1766 lists are not known, they must have varied. Some of the merchants, such as Dirk Knipping and Pieter Ouckama, were still young, while David da Costa had lived in Izmir for twenty-three years already. It was common practice for traders to send one of their sons abroad, as was for instance the case for the firm of Thomas de Vogel \& Zoon. One of the sons, also named Thomas, was sent to Izmir, while another son, Leonard Thomas, remained a partner in Amsterdam. ${ }^{221}$ In other cases, merchants' sons were employed by firms abroad with whom they corresponded so they could learn the ropes of the trade. When Pieter Ouckama and Dirk Knipping initiated a partnership in Izmir in 1759, they employed the son of Pieter Kikkert from Texel, but they sent him back to his parents due to bad behaviour. ${ }^{222}$ It was fairly common for the larger Dutch partnerships in Izmir to employ scribes. It seems to have been far less common for these scribes to become independent traders in their own regard. Of the sixteen men registered as scribes in 1759, three had been there already for more than ten years. Only one of those three, Arnoldus Wissing, a scribe for the firm of Clement, van Sanen, van der Zee \& $\mathrm{C}^{\circ}$, was still there in 1766 . Keun and Slaars, scribes for Daniel Fremeaux, were also still there, as well as Frans Duytz, a scribe for the firm of van Lennep \& Enslie, and Moses Pereira, who was a scribe in the service of the Dutch treasury. Only Jacob de Vogel, who had come from Rotterdam and was unrelated to Thomas de Vogel from Amsterdam, had moved up to become a partner in the firm of Jacob \& George de Vogel - after a controversial association with an Ottoman Greek. ${ }^{223}$ Everything suggests that the Dutch trading community was fairly stable in composition. What changed the most were the associations that these merchants formed with one another.

220 Heeringa and Nanninga, Bronnen tot de geschiedenis, 4: pp. 56-58, Consul Daniel Jean de Hochepied to Ambassador Willem Dedel, Izmir, o8/12/1766; see tables 2 and 3 .

221 The business archives of the de Vogel firm in Amsterdam have been preserved for the period $1685^{-1804}$ in the family archives. City Archives Amsterdam (hereafter CAA), $\mathrm{N}^{\circ} 33^{\circ}$ ('Archief van de familie de Vogel en aanverwante families') (hereafter CAA/ADV), containing the family's archives and business papers dated between 1608 and 1960.

222 NACS, $\mathrm{N}^{\circ} 490$ ('Register van uitgaande brieven van het handelshuis Knipping \& Ouckama, 1759-1761'), Knipping \& Ouckama to Pieter Kikkert, Izmir, 20/10/1759.

223 For Jacob de Vogel, see pp. 283-288. 
A second feature was the frequent bachelor status of the Dutch merchants in Izmir. This fits within classic interpretations of European merchants remaining single and is not surprising when considering that most of them must have been quite young. ${ }^{224}$ It is, however, still somewhat remarkable in light of new research showing that, by the eighteenth century, it was not so uncommon for European merchants to bring wives with them to the Levant. ${ }^{225}$ In spite of the growing presence of European women in Levantine cities, twenty-seven men, more than half the men that made up the Dutch community of Izmir, were not married, and table 2 shows that there is no clearly discernible correlation between the time merchants had resided in Izmir when the list was compiled and their marital status. ${ }^{226}$ Of the men who were married, only three had Dutch wives: David van Lennep married Anne Marie Leystar, daughter of a Dutch trader (see figure 6), and Giovanni Giera, a Genoese merchant, and Clement van der Laan, a Dutch shopkeeper, both had Dutch wives. Seven men had European wives (French, Italian or German), one had a wife from Izmir, and the origins of the wife of Daniel Chaves were not mentioned. Five men had Greek wives, something that stirred great controversy in the $176 \mathrm{os}$. The Greek bishop in Izmir was afraid these marriages would come at the expense of the Greek Orthodox community and petitioned the Ottomans to forbid marriages between Greek women and western European men. ${ }^{227}$ Although a formal restriction was never issued, the quarrels with the Greek bishop seriously troubled the Dutch community. Not everybody appreciated such interfaith marriages. Dirk Knipping had started out in Izmir working in the office of David van Lennep for seven months, until he was made partner in the firm that was renamed David van Lennep, Knipping \& Enslie. The marriage of van Knipping to a local Greek woman angered David van Lennep, and Knipping's involvement in the firm was terminated following a clause in the partnership

\footnotetext{
224 Wood, A history of the Levant Company, p. 244.

225 Van den Boogert, 'Negotiating foreignness', p. 35.

226 Although it is possible that some of the merchants who had been there a long time were widowers.

227 NACS, $\mathrm{N}^{\circ} 223$ ('Papieren raakende de Grieken met de Franken weegens trouw \& veranderen der religie \&c in maend meij $1767 \mathrm{t}^{\prime}$ laeste $25 \mathrm{~d}^{\prime}$ ). Mixed marriages were often considered dangerous as they were considered to have the potential to upset the existing demographical balance between the different religious denominations. For a critical discussion of this, see van den Boogert 'Negotiating foreignness', pp. 35-40; as well as Ian Coller, 'East of enlightenment: Regulating cosmopolitanism between Istanbul and Paris in the eighteenth century', Journal of world history, 21:3 (2010): pp. 453-454.
} 
contract that allowed van Lennep to do so in case of a marriage he did not approve. $^{228}$

Changing partnerships, such as Knipping's involvement with van Lennep and Enslie and later with Pieter Ouckama, were not uncommon amongst the Dutch trading community of Izmir, and several partnerships were set up and dissolved within a few years. When they were not partners, it was rare for them to engage in business with one another. Firms were competitors with one another in their efforts to obtain commissions from Europe, but this did not necessarily make them antagonists. The Dutch community of Izmir was small, and traders not only competed with each other but also with the merchants of other trading nations. Additionally, every merchant needed a favour from a colleague every once in a while, and the mutual granting thereof was quite normal amongst early modern traders. While the Dutch merchants in Izmir were not accustomed to do business with each other, they could have shared interests with the same correspondents. The firm of David van Lennep, for instance, was a correspondent with and worked on commission for Thomas de Vogel \& Zoon in Amsterdam. One of Thomas' sons resided in Izmir and also acted as an agent for him. Additionally, de Vogel's firm in Amsterdam did business on behalf of van Lennep as well as the son, while Thomas de Vogel in Amsterdam was also the accountant for a ship active in Levant navigation, the Vogel Fenix (Phoenix Bird), for which they owned a part, but van Lennep owned an equal part.229

Even though there were no marital alliances to strengthen ties within the Dutch community, or with other Protestant communities, the Dutch who lived in Izmir must have interacted socially with one another, and with other Europeans. They all lived in a particular neighbourhood, and at times they shared housing. Most merchants rented houses from Ottomans, which were located, together with the warehouses, in khans, and several of them lived together. ${ }^{230}$ The Ottoman list of Dutch community members in 1766 , for instance, mentioned Thomas de Vogel as living with van Lennep and Enslie.

228 CAA/ADV, $\mathrm{N}^{\circ} 36$ ('Kopieboek', 1758-1759), pp. 56-58, Thomas de Vogel \& Zoon to David van Lennep, Amsterdam, o6/o6/1758; and pp. 175-177, Thomas de Vogel \& Zoon to David van Lennep, Amsterdam, 21/o7/1758.

229 Both owned three-sixteenths of the vessel. CAA/ADV, N ${ }^{\circ} 7$ ('Redersboek van het schip De Vogel Phenix', 1752-1758). Later, they also owned parts in De Vrouwe Catharina. Heeringa and Nanninga, Bronnen tot de geschiedenis, 4: pp. 190-192, Thomas de Vogel \& Zoon to David van Lennep \& Enslie, Amsterdam, 23/o8/1765; see also ibid., pp. 503-526 for several accounts of voyages made by the De Vrouwe Catharina.

230 Khans were communal buildings, large and square, built around a courtyard and owned by Muslim Ottomans, where Europeans rented living and warehouse space. See, for instance, Masters, 'Aleppo', p. 26; and de Groot, The Ottoman Empire, p. 131. 
When their partnership was dissolved in 1792, David van Lennep's son Jacob expressed his contentment with being able to set up a new firm with a Swiss trader rather than having to deal with Enslie, who he felt was an 'angry, sore man', unmarried and living in the same house as the van Lennep family. Jacob van Lennep felt that Enslie had made their lives miserable, while he was spending most of his profit on a luxurious lifestyle. ${ }^{231}$

\subsection{Levantine Commission Trade}

Dutch trading communities such as the one in Izmir played a specific role in commerce. Hermann Wätjen asserted that in the seventeenth century, most Dutch traders in the Levant fell into two categories; they were either brokers working for a commission fee on behalf of merchants in the United Provinces or junior partners representing firms in the Dutch Republic. ${ }^{232}$ The organisation of Dutch Levant trade at the time resembled the French and English systems that relied on 'factors', agents who were employed by firms at home. English Levant traders were united in the Levant Company, which maintained a monopoly over Anglo-Levant trade. The agents that the company sent abroad were often 'the sons of freemen or of gentlemen and cadets of noble families.' ${ }^{233}$ In the French case, principals in Marseille employed French agents in the Levant to process their commissions. These agents, régisseurs, did not trade on their own as independent firms, and their number was limited by the Marseille Chamber of Commerce. ${ }^{234}$

French and English systems of hierarchy stayed essentially the same throughout the eighteenth century, but the Dutch system allowed for more freedom. By the mid-eighteenth century, Dutch Levant trade had evolved into a system in which most traders in the Levant worked as independent firms that were engaged in a variety of short-term and longer-term commercial partnerships, while still maintaining their role as commission agents. ${ }^{235} \mathrm{~A}$ big difference between them and their French and English colleagues was that Dutch

231 Heeringa and Nanninga, Bronnen tot de geschiedenis, 4: pp. 1265-1266, Jacob van Lennep to Leonard Thomas de Vogel, Izmir, 17/11/1792. Not much is known of the general lifestyle of the Dutch merchant community in Izmir.

232 Wätjen, Die Niederländer, pp. 184-189.

233 Hakkı Kadı, Ottoman and Dutch merchants, p. 158. For the English factors, see Ralph Davis, Aleppo and Devonshire Square. English traders in the Levant in the eighteenth century (London, 1967).

234 For the French Levant trade in Izmir in the eighteenth century, see Sébastien Lupo, 'Révolution(s) d'échelles. Le marché levantin et la crise du commerce marseillais au miroir des maisons Roux et de leurs relais à Smyrne (1740-1787)' (unpublished PhD thesis, Aix-Marseille Université, 2015).

235 Hakkı Kadı, Ottoman and Dutch merchants, pp. 16o-161. 


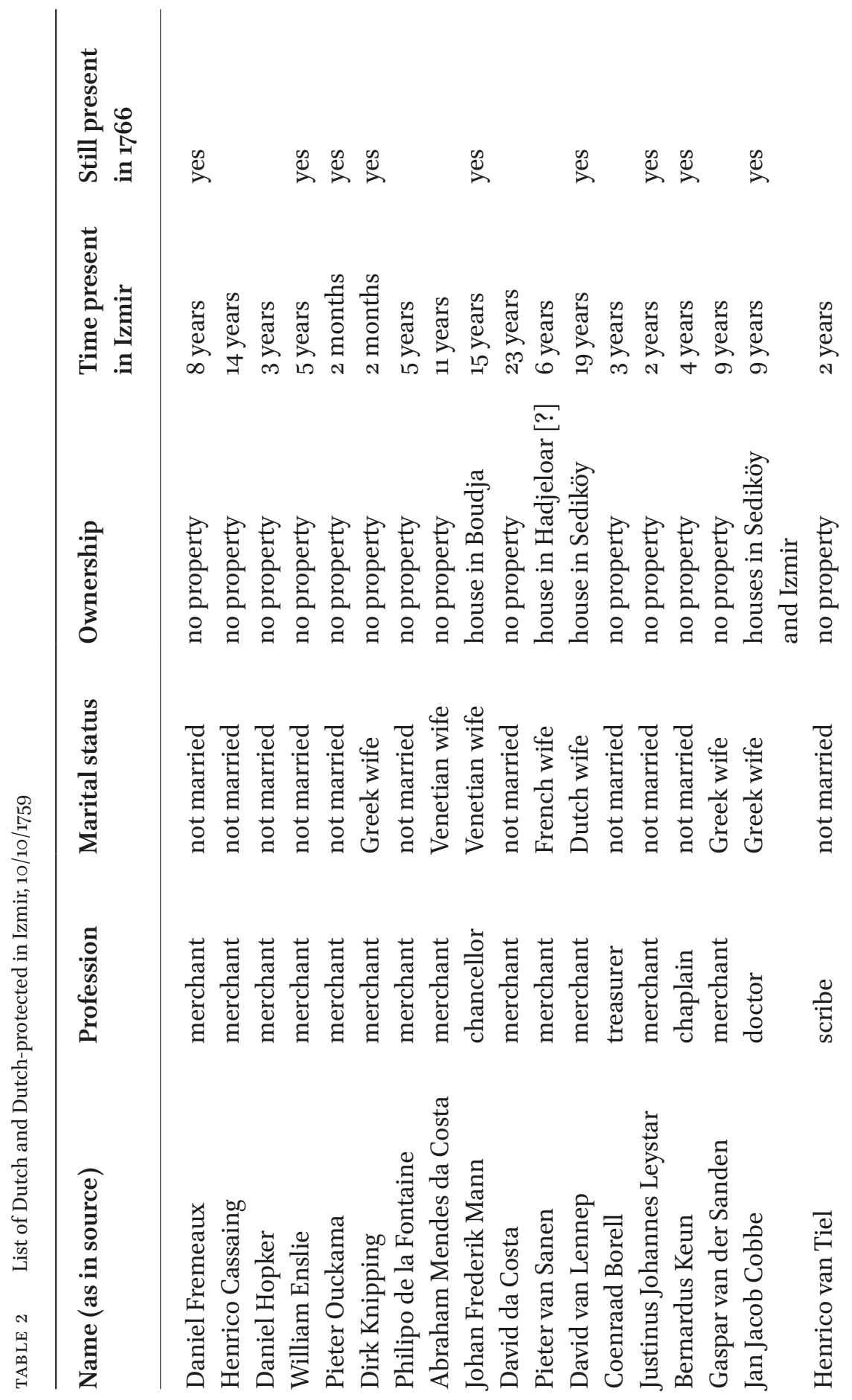




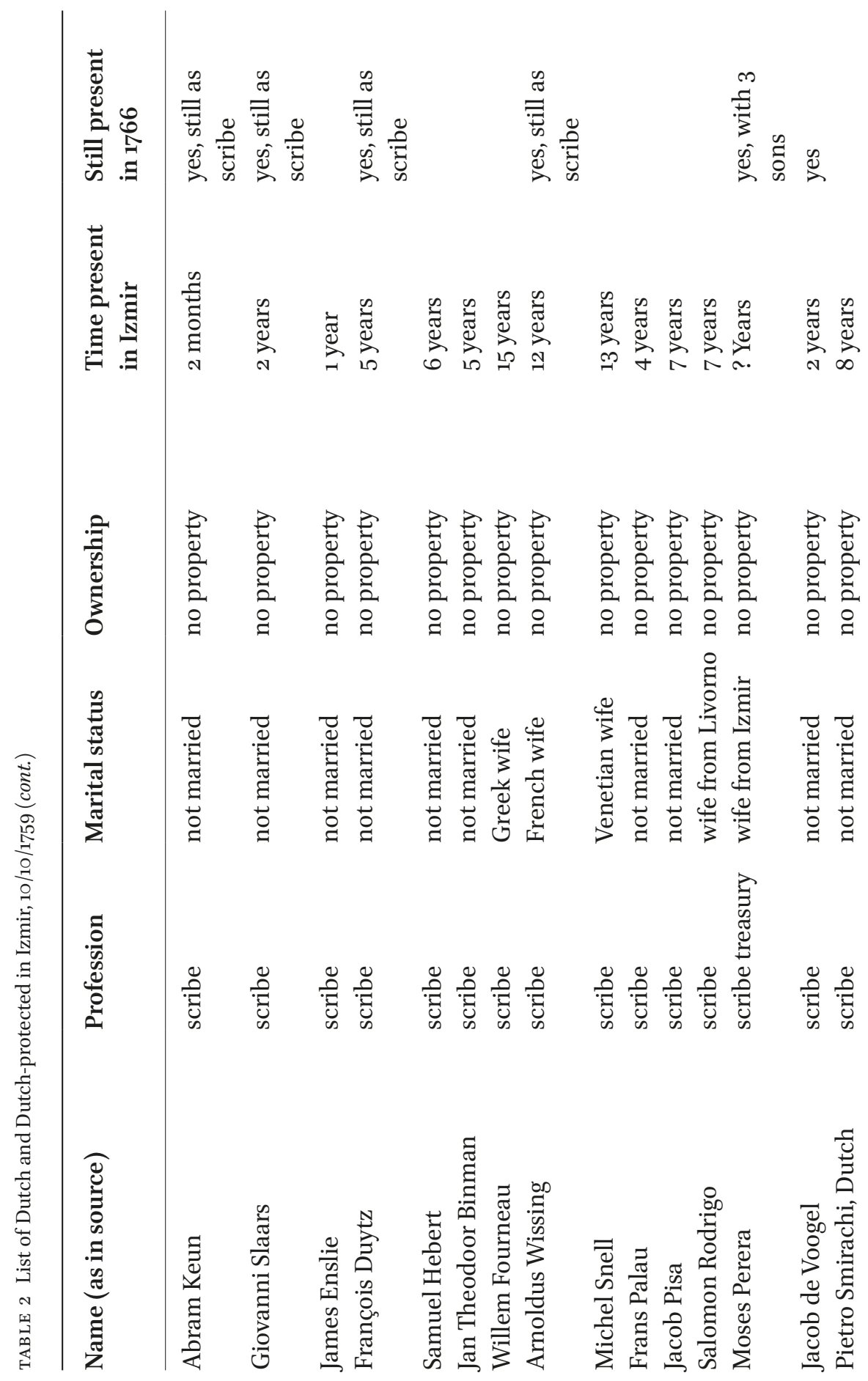



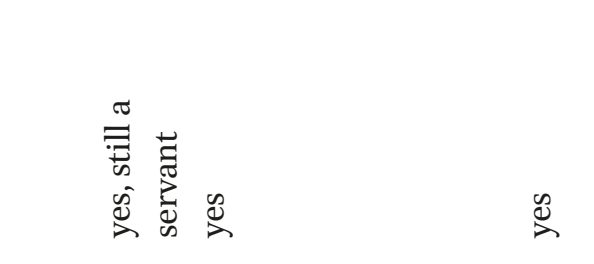

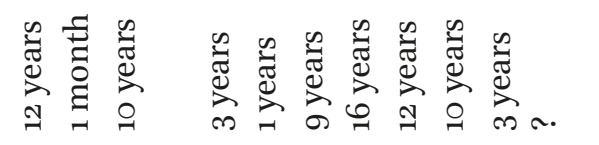

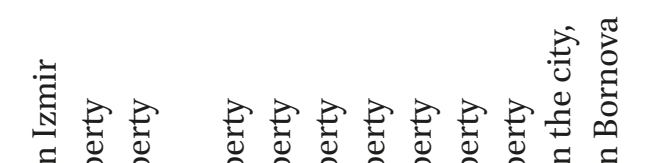

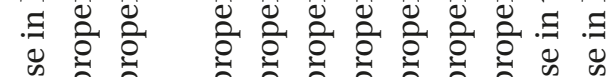

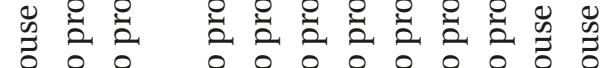



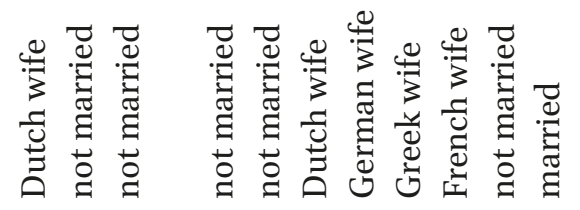

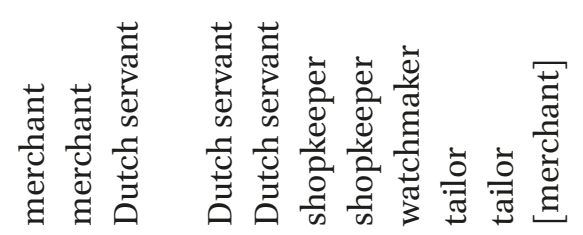

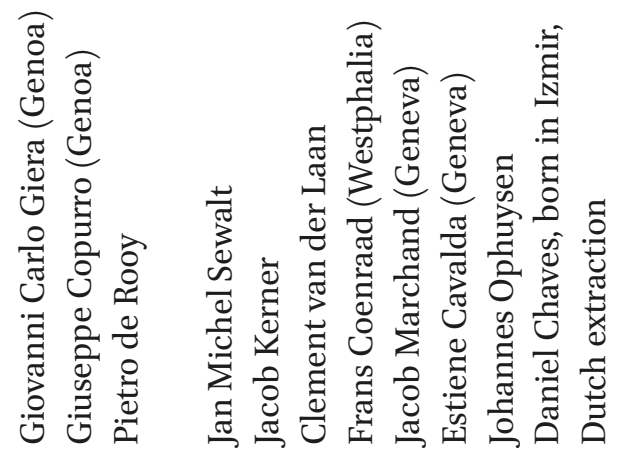


TABLE 3 New members of the Dutch community in 1766

\begin{tabular}{|c|c|c|c|}
\hline Name & Profession & Name & Profession \\
\hline George de Vogel & Merchant & $\begin{array}{l}\text { Jan van den Broek } \\
\text { (Amsterdam) }\end{array}$ & $\begin{array}{l}\text { Servant for van } \\
\text { Lennep \& Enslie }\end{array}$ \\
\hline Diodato Abro & $\begin{array}{l}\text { dragoman in the } \\
\text { service of the } \\
\text { Directorate of } \\
\text { Levant Trade }\end{array}$ & $\begin{array}{l}\text { Esaias Fercken } \\
\text { (Liège) }\end{array}$ & $\begin{array}{l}\text { scribe for van } \\
\text { Sanen \& van der } \\
\text { Zee }\end{array}$ \\
\hline Costala Amira & $\begin{array}{l}\text { dragoman in the } \\
\text { service of the } \\
\text { Directorate of } \\
\text { Levant Trade }\end{array}$ & $\begin{array}{l}\text { J.M. Snell } \\
\text { (Hessen-Cassel) }\end{array}$ & $\begin{array}{l}\text { scribe for van } \\
\text { Sanen \& van der } \\
\text { Zee }\end{array}$ \\
\hline Pitako Hagi & beratlı & Hendrik & scribe for van \\
\hline Anton Oglou & & $\begin{array}{l}\text { Bortendorf } \\
\text { (Hamburg) }\end{array}$ & $\begin{array}{l}\text { Sanen \& van der } \\
\text { Zee }\end{array}$ \\
\hline Missier di Jagia & beratlı & $\begin{array}{l}\text { Christiaan } \\
\text { Roodermeulen } \\
\text { (Amsterdam) }\end{array}$ & $?$ \\
\hline Chelik Torec & beratlı & $\begin{array}{l}\text { A. Beaune } \\
\text { (Amsterdam) }\end{array}$ & $?$ \\
\hline Isaie di Massé & beratlı & Gerrit van Brakel & [merchant] \\
\hline Adam di Morco & beratlı & $\begin{array}{l}\text { Johan Antoni } \\
\text { Coenraad } \\
\text { (Bohemia) }\end{array}$ & glass seller \\
\hline Abram Asecri & beratlı & $\begin{array}{l}\text { Johan Fredrik } \\
\text { Coenraad } \\
\text { (Bohemia) }\end{array}$ & glass seller \\
\hline Janatie Malgos & $\begin{array}{l}\text { in the service of } \\
\text { the Directorate of } \\
\text { Levant Trade }\end{array}$ & $\begin{array}{l}\text { Antoni Habel } \\
\text { (Bohemia) }\end{array}$ & glass seller \\
\hline Gualtero Gallo & $\begin{array}{l}\text { in the service of } \\
\text { the Directorate of } \\
\text { Levant Trade }\end{array}$ & $\begin{array}{l}\text { Auner van } \\
\text { Zeevenbergen }\end{array}$ & surgeon \\
\hline Jorgatie Amira & $\begin{array}{l}\text { in the service of } \\
\text { the Directorate of } \\
\text { Levant Trade }\end{array}$ & Radman van Clef & cutter \\
\hline $\begin{array}{l}\text { Isaac van } \\
\text { Oudermeulen }\end{array}$ & $\begin{array}{l}\text { scribe for } \\
\text { Fremeaux }\end{array}$ & Namer van Dresde & cutter \\
\hline
\end{tabular}


TABLE 3 New members of the Dutch community in 1766 (cont.)

\begin{tabular}{llll}
\hline Name & Profession & Name & Profession \\
\hline Thomas de Vogel & $\begin{array}{l}\text { lives with van } \\
\text { Lennep and }\end{array}$ & Joh. Kraus & carpenter \\
& $\begin{array}{l}\text { Enslie } \\
\text { scribe for van } \\
\text { Lennep \& Enslie }\end{array}$ & Ludecke van Halle & vicar \\
& & \\
\hline
\end{tabular}

SOURCE: NACS, $\mathrm{N}^{\circ} 14$, CONSUL DANIEL JEAN DE HOCHEPIED TO AMBASSADOR WILLEM DEDEL, IZMIR, 08/12/1766

merchants offered their services to a variety of firms in the United Provinces and elsewhere, rather than being employed by one particular firm. A second difference was that the Dutch institutional environment allowed for a much higher degree of freedom - which eventually led to the non-Muslim Ottoman penetration of Dutch trade networks with the Levant. ${ }^{236}$

The Dutch, like the other European merchants in Izmir, were involved in what was essentially an exchange trade. They received a variety of products from the United Provinces, which were sold in Izmir to Ottoman merchants. Goods included arms, spices, pepper, coffee, sugar, tin, steel, grain and wheat, but also textiles such as linen and blankets. In particular, woollen cloth, camlets and says produced in Leiden, the leading textile-producing centre of the United Provinces, were a popular export product sent to the Mediterranean. ${ }^{237}$ In return, Dutch traders mainly bought raw materials for textile production in Dutch cities, such as cotton, silk, wool or mohair yarn, on behalf of firms in the United Provinces. $^{238}$

Networks of trade developed that connected firms in the United Provinces not only to Dutch traders in Izmir but also to Ottoman non-Muslim merchants who

\footnotetext{
236 A process described in detail in ibid.

237 For an extensive study, see N.W. Posthumus, De geschiedenis van de Leidsche lakenindustrie, 3 vols. (The Hague, 1908). One substantial archive of a cloth merchant was preserved in Leiden, that of Daniël van Eys. He traded extensively with the Levant, and one of his younger brothers was a Director of Levant Trade. See J.W. Veluwenkamp, 'De Leidse lakenondernemer Daniël van Eys, 1688-1739', Jaarboekje voor geschiedenis en oudheidkunde van Leiden en omstreken, 84 (1992): pp. 109-124.

238 Bulut, Ottoman-Dutch economic relations, pp. 168-169.
} 
acted as intermediaries, doing business on behalf of Europeans with Ottoman customers and suppliers, including Muslims. These intermediaries went by the name of sensal and came from the ranks of different non-Muslim Ottoman subjects well-versed in trade, such as Jews, Armenians and Greek. ${ }^{239}$ They were brokers, buying goods from locals in various Ottoman cities destined for export and selling the merchandise that Europeans had shipped to the échelles. ${ }^{240}$ They were paid a percentage of the transaction as fee that was raised by both parties. These sensals were thus a second type of intermediary in Dutch Levant trade, next to the Dutch traders in Izmir themselves. These men were traders in their own regard, and although they did not obtain any official privileges in the capitulations, the various Ottoman middlemen, which also included Ottoman scribes and warehousemen (mahzencis), obtained the same tax privileges as the Europeans and the dragomans during the eighteenth century. ${ }^{241}$ It was important for Dutch and other European trading houses to find reliable sensals who could be trusted and stick with them. When Guillaume Cusson, one of the régisseurs of the Roux firm of Marseille, arrived in Izmir, he wrote that 'I do not have any sensals yet, because for [obtaining the services] this kind of persons one needs to make a careful approach and make the right choice, which is not a matter of one or two days.'. ${ }^{242}$

This group of Ottoman sensals, which consisted of Armenian, Greek and Jewish Ottomans, managed to overcome their Dutch colleagues in Izmir as intermediaries between the United Provinces and the Levant. They controlled Izmir's internal trade and connections with Ottoman trade circuits further inland. ${ }^{243}$ Several of these sensals became successful traders on their own, sometimes after they had been able to secure a berat. Some of them even started to employ Dutch scribes. In 1768, for instance, Manolaki di Panaiotis, a

239 The word derived from the Arabic 'simsār', meaning agent, and itself of Persian origin. It was altered to 'sensale' in Italian, used by Venetians, and became the term in other European languages to indicate the Ottoman intermediaries in Levantine trade. See S.D. Goitein, Economic foundations, vol. 1 of A Mediterranean society. The Jewish communities of the world as portrayed in the documents of the Cairo Geniza (Berkeley, Los Angeles, and London, 1967), p. 160.

240 Marie-Carmen Smyrnelis, 'Courtiers de Smyrne (fin du XVIIIe-milieu du XIX siècle). Médiateurs professionnels et médiations dans l'Empire ottoman', in Hommes de l'entredeux: parcours individuels et portraits de groupes sur la frontière de la Méditerranée, XVIeXXe siècle, eds. Bernard Heyberger and Chantal Verdeil (Paris, 2009), p. 120.

241 Van den Boogert, The capitulations, pp. 70-72; see also his 'Ottoman intermediaries in the 18th century: Analysis of a "dirty trade", Oriente moderno, 93:2 (2013): pp. 515-530.

242 Quoted in Lupo, 'Révolution(s) d'échelles', p. 98, 'Je n’ai pas encore des censseaux, pour ces sortes des gens il faut aller doucement et en faire un bon choix, ce qui n'est pas l'affaire d'un ou deux jours'.

243 Frangakis-Syrett, The commerce of Smyrna, p. 104. 
Greek trader who purchased French protection, signed a contract with a man from Leiden named Nicolaas Johannes Boonhoff. ${ }^{244}$ Boonhoff was to work for di Panaiotis for five years but was fired after less than two years. According to Boonhoff, di Panaiotis had refused to pay for a language instructor that Boonhoff had hired in order to learn French and Italian. This went against the terms agreed upon in the contract. He also did not understand why di Panaiotis accused him of using curse words and of being 'a traitor of his firm'. ${ }^{245}$ Because di Panaiotis refused to pay for debts Boonhoff had made, Boonhoff could not leave Izmir, which is why he filed a complaint at the court of the Dutch consul. 246

The outcome of the case was not registered, but the employment of Dutch scribes by Ottoman merchants involved in trade with the United Provinces was clearly visible. They could help with writing and translating letters and maintaining correspondence with firms in the United Provinces, lessening the need for these Ottomans to procure Dutch partners in Izmir. Some also formed intercultural partnerships with Dutch merchants, a practice the Dutch considered harmful to their national interests and was later forbidden. ${ }^{247}$ The French and English commercial operations in the Levant were more tightly controlled, but the Dutch policies of freer trade allowed for the gradual overtaking of Dutch Levant trade by Armenian, Jewish and Greek Ottoman traders who attempted to bypass the Dutch traders in Izmir to deal directly with traders in the United Provinces, a process facilitated through the growing presence of their fellow countrymen in the United Provinces. ${ }^{248}$ The Armenians were the first Ottomans to establish themselves in Amsterdam during the seventeenth century, and they were mostly active in the trade in mohair yarn. They found an existing Jewish community, and in the eighteenth century, they were joined by Greek merchants specialising in cotton. ${ }^{249}$

244 NACs, $\mathrm{N}^{\circ} 346$ ('Proces tusschen de heeren M: K:r di Panajottis en haar schrijver Joh: Boonhoff van 6 tot 13 april 1770'), 'Contract van Boonhoff met M Kiriaco \& $\mathrm{C}^{\circ} 1768$ ', Izmir, 22/12/1768.

245 NACS, $\mathrm{N}^{\circ} 346$, 'Request van NJ Boonhoff weeg eenige differentie met Ml Kiriaco di Panajottis \& $\mathrm{C}^{\circ}$ ', Izmir, 13/04/1770, '[...] een verrader van zijn huys [...]'.

246 Ibid.

247 See pp. 281-29o.

248 See the chapter 'Ottoman merchants in Amsterdam' in Hakkı Kadı, Ottoman and Dutch merchants, pp. 198-234.

249 Maurits van den Boogert, 'Ottoman Greeks in the Dutch Levant trade: Collective strategy and individual practice (c. 1750-1821)', Oriente moderno, nuova serie, 86:1 (2006): pp. 129-147. For Jewish traders in the United Provinces, see Daniel Swetschinski, Reluctant cosmopolitans: The Portuguese Jews of seventeenth-century Amsterdam (Oxford, 2000); Jonathan Israel and Reinier Salverda, eds., Dutch Jewry: Its history and 
Dutch authorities quickly became worried about the growing presence of Ottoman merchants in their trade, and merchants in the United Provinces regularly expressed the fear that Ottomans would take over Dutch Levant trade completely in the letters they sent to their Dutch correspondents in Izmir. ${ }^{250}$ An additional source for worry was the growing competition from other European trading communities. In 1688, Dutch exports of fine woollen textiles had risen from 3,00o to 6,0oo half-pieces. This number had fallen to 3,000 again by the beginning of the eighteenth century, an evolution largely caused by competition from French textiles and English imitations of Dutch textiles. ${ }^{251}$ After the War of Spanish Succession, the Dutch lost ground to the French in the Levant, and it was never recovered, partially due to protective tariffs established in Marseille. ${ }^{252}$

In a 1754 memoir on Dutch trade, Elbert de Hochepied, the ambassador in Istanbul, suggested that the Dutch traders in Izmir had been the victim of the success of the trade between the Ottoman Empire and the United Provinces. He stated that the volume of trade in Izmir was too big to be handled by the Dutch community there, so they started to count on foreigners (i.e., Ottomans) to sell their merchandise in Istanbul and Salonika. They also looked to these foreign contacts to purchase goods for the return voyage to the Dutch Republic, which led to the additional payment of commissions in Istanbul and Salonika, next to the payment of transport costs in Izmir, something that caused an unnecessary price rise. According to de Hochepied, this led to foreigners becoming rich from Dutch trade, while there were not even five Dutch traders who 'had been able to retire in the motherland with a not so considerable fortune..253

secular culture (1500-2000) (Leiden and Boston, 2002); Jonathan Israel, Diasporas within a diaspora: Jews, crypto-Jews and the world maritime empires (1540-1740) (Leiden and Boston, 2002); and Herbert I. Bloom, The economic activities of the Jews of Amsterdam in the seventeenth and eighteenth centuries (Williamsport, 1937). For the Armenians, see René Arthur Bekius, 'The Armenian colony in Amsterdam in the seventeenth and eighteenth centuries: Armenian merchants from Julfa before and after the fall of the Safavid Empire', in Iran and the world in the Safavid age, eds. Willem Floor and Edmund Herzig (London and New York, 2012), pp. 259-284; Aslanian, From the Indian Ocean, pp. 8o-81; and Kéram Kévonian, 'Marchands arméniens au XVIIe siècle, à propos d'un livre arménien publié à Amsterdam en 1699', Cahier du monde russe et soviétique, 16:2 (1975): pp. 199-244.

250 For a thorough discussion, see the chapter 'The Ottoman penetration of Dutch trading networks' in Hakkı Kadı, Ottoman and Dutch merchants, pp. 170-197.

251 Ibid., p. 165 .

252 Frangakis-Syrett, The commerce of Smyrna, pp. 164-169.

$253 \mathrm{NA}, \mathrm{N}^{\circ} 2.21 .006 .46, \mathrm{~N}_{2}^{\circ}$ ('Mémoire pour le commerce', 1754), $\mathrm{f}_{4} 4 \mathrm{v}$, '[...] depuis cinquante ans, se soyent retirez à la patrie, avec quelque fortune un peu considerable $[\ldots]$ '. 
Furthermore, de Hochepied suggested that firms in Amsterdam and Rotterdam no longer trusted the Dutch traders in Izmir to execute their commissions to satisfaction. De Hochepied felt the number of Dutch trading houses should be fixed, to stop competition between one another, and that partnerships needed to be rearranged to win back the trust that had been lost. The ambassador felt that 'the principal merchants could incorporate their family members or friends there [in the new partnerships in Izmir] and become involved there with knowledge, security and profit. ${ }^{254}$ De Hochepied blamed the independence of Dutch merchants in Izmir for their decline, and his text was meant as a call to go back to the situation of the seventeenth century, when Dutch traders in Izmir were employed as permanent agents by firms back home rather than acting as independent intermediaries working for everyone.

Elbert de Hochepied was not the only ambassador to consider the matter of Dutch national commercial interest and its decline in the face of a growing presence of Ottoman traders. In 1765 , Willem Gerrit Dedel wrote to the Directorate of Levant Trade about the disadvantage Dutch merchants had in comparison to Ottoman traders. Dutch traders were obliged to take a national oath in which they promised to adhere to regulations. Dedel argued that the absence of such an oath for Ottoman traders such as the protégés made them resort to fraud much more frequently, creating a dishonest situation. Even though it is impossible to assess whether Dedel's observation was in any way correct, it is still an important consideration. An oath was a strong instrument that could be used in court as legal proof. While it is certainly naïve to think that Dutch merchants were hindered from committing fraud simply by taking an oath, it was a valid tool at the disposal of the authorities, and it was not for nothing that Dutch merchants had objected so strongly in the 1670 s when they were forced to take it. ${ }^{255}$

Additionally, the national oath forced Dutch merchants to provide Dutch officials access to their commercial paperwork so the share of ambassadorial and consular taxes they needed to pay could be determined correctly. This was a financial burden that did not apply to Ottomans (unless they were protégés, but their status exempted them from certain Ottoman taxes), and Dedel felt it was time to make them pay a financial contribution for the institutions that had been introduced to foster the commerce in which they were now playing an integral part. Dedel explained that the oath had been introduced in 1675 at a time when Ottoman traders were still 'inexperienced in trade, and we did the

\footnotetext{
254 Ibid., ${ }^{\circ} 5 \mathrm{r}$, '[...] les principaux negociants pourront y incorporer de leurs parents, ou amis, et sy interesser avec connoissance, seureté, et profit [...]'.

255 For the disputes in the 1670 and 168os, see pp. 81-82 and 99-103.
} 
commerce here.'256 Dedel referred to the overseas trade between the United Provinces and the Levant, and he added that since 1675, Ottoman traders had established themselves in the United Provinces, and Dutch firms at home had started to consign goods directly to Ottoman firms in the Levant, rather than only to Dutch firms. ${ }^{257}$ The directors replied that freedom of trade was 'a very delicate matter', and they feared it would be difficult to put a stop to Ottoman influence over Dutch Levant trade. ${ }^{258}$ By the 1770 , about half of the Dutch Levant trade was in the hands of Greek merchants, often with Chiot origins. ${ }^{259}$

The response of the directors demonstrated the disagreement within Dutch institutions on how to deal with the Ottoman presence. While many merchants and diplomats pressed for concrete measures, others did not want to obstruct the principles of free trade, and several actions undertaken in Izmir in the late eighteenth and early nineteenth centuries that were aimed against Ottoman traders met with disapproval from the Directorate of Levant Trade back home. ${ }^{260}$ In spite of this difference of opinion, measures were taken in an attempt to protect Dutch merchants in the Levant. During the 176 os, the Dutch reacted by establishing new tariffs for consular duties, a restriction on intercultural partnerships between Dutch nationals and Ottomans, and the establishment of an additional duty of $5 \%$ on all goods that reached the United Provinces on foreign (non-Dutch) ships. At the end of the eighteenth century, several voices even advocated for the introduction of a monopoly to protect Dutch Levant trade, but this was never implemented. Throughout this century, the Dutch trading community in Izmir remained relevant in the trade between Europe and the Levant but never on the same scale as had been the case during the seventeenth century. ${ }^{261}$ Between 1775 and 1789 , the export out of Izmir to Dutch ports amounted to $22.5 \%$ of the total export of the city to Europe. On the import side, the Dutch share amounted to $18 \%{ }^{262}$ During the

256 Heeringa and Nanninga, Bronnen tot de geschiedenis, 4: pp. 17-20, Ambassador Willem Dedel to the Directorate of Levant Trade, Istanbul, o2/11/1765, on p. 18, '[...] nog zeer onbedreeven in den handel en de negotie wierd hier door ons gedreeven'.

257 Ibid.

258 Heeringa and Nanninga, Bronnen tot de geschiedenis, 4: pp. 32-34, Directorate of Levant Trade to Ambassador Willem Dedel, Amsterdam, 24/12/1765, on p. 32, '[...] een seer delicaate saak $[\ldots]$ '.

259 Frangakis-Syrett, The commerce of Smyrna, p. 100.

26o Hakkı Kadı, Ottoman and Dutch merchants, pp. 272-273.

261 On these measures, see the chapter on 'The transformation of Dutch trade policies in the Levant: From free trade to "faint" protectionism' in Hakkı Kadı, Ottoman and Dutch merchants, pp. 237-273.

262 Frangakis-Syrett, The commerce of Smyrna, p. 168. 
Napoleonic wars, British sea blockades put a complete halt to Dutch maritime trade with the Ottoman Empire, and in the early nineteenth century, the Dutch shared the same malaise as the French. By 1820, it was American and British merchants that dominated Izmir's trade with the western world. ${ }^{263}$

263 Ibid., p. 186. 